University of Rhode Island

DigitalCommons@URI

Open Access Dissertations

1990

\title{
Paternal Acceptance and Nurturance Received and Parents' Acceptance and Nurturance of Their Children
}

Michael Hansen

University of Rhode Island

Follow this and additional works at: https://digitalcommons.uri.edu/oa_diss

\section{Recommended Citation}

Hansen, Michael, "Paternal Acceptance and Nurturance Received and Parents' Acceptance and Nurturance of Their Children" (1990). Open Access Dissertations. Paper 1018.

https://digitalcommons.uri.edu/oa_diss/1018

This Dissertation is brought to you for free and open access by DigitalCommons@URI. It has been accepted for inclusion in Open Access Dissertations by an authorized administrator of DigitalCommons@URI. For more information, please contact digitalcommons-group@uri.edu. 
PATERNAL ACCEPTANCE AND NURTURANCE RECEIVED AND

PARENTS' ACCEPTANCE AND NURTURANCE OF THEIR CHILDREN

BY

MICHAEL HANSEN

A DISSERTATION SUBMITTED IN PARTIAL FULFILLMENT OF THE REQUIREMENTS FOR THE DEGREE OF DOCTOR OF PHILOSOPHY

IN

PSYCHOLOGY

UNIVERSITY OF RHODE ISLAND

1990

28329889 


\section{ABSTRACT}

The relationship of perceived paternal nurturance and acceptance and parents' nurturance and acceptance of their children was investigated. Two-hundred and fifty (250) undergraduate students and their parents participated in the study. Each subject completed an abbreviated version of the Family Data Form (FDF), which was used to obtain individual and family demographic information. The Family Relations Inventory (FRI) was utilized to measure subjects' perceptions of the degree of parental nurturance and acceptance received. In addition, students completed the Comrey Personality Scales (CPS). Interrelationships between students' and parents' perceived nurturance and acceptance were examined through the utilization of a structural equation model. Fathers' perceived paternal nurturance was shown to relate significantly to both sons' and daughters' perceptions of paternal nurturance received, whereas, parents' perceived paternal acceptance was not found to be significantly related to children's perceptions of parental acceptance across all subject groups.

Multivariate analyses of variance were also conducted to assess interrelationships between students' perceived paternal involvement and their scores on the personality adjustment measures. Paternal nurturance was found to be significantly related to subjects' personality adjustment, but no significant findings were obtained for the relationship of paternal acceptance and the personality adjustment measures. Implications of these findings as well as suggestions for future research concerning the father-child relationship are discussed. 
I would like to express my sincere gratitude and appreciation to the members of my dissertation committee: Drs. Henry Biller, Joseph Rossi, and Thomas Gunning, for their assistance and support during the preparation and defense of this dissertation.

Special thanks is extended to Henry Biller, whose knowledgeable insights, guidance, and personal support were instrumental to the completion of this work.

Special appreciation is also extended to Joe Rossi for his availability, guidance, and assistance through all phases of this project.

Moreover, I wish to thank Jeff Bellis for his assistance with data analysis and Frank Rouleau and Adrienne Newsome for their technical assistance with word processing.

Finally, I am most grateful to my wife, Abina, and our sons Christopher, Daniel, and Matthew, for the opportunity to experience the gift of fatherhood. 
LIST OF TABLES................................ v

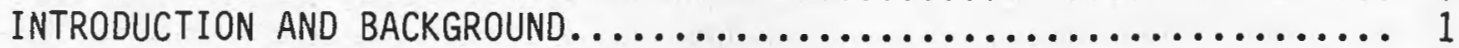

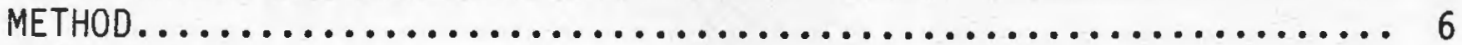

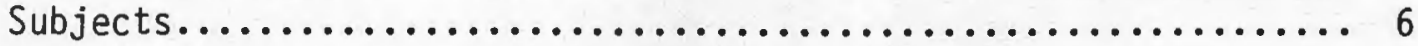

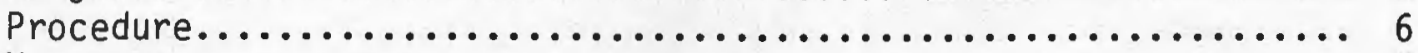

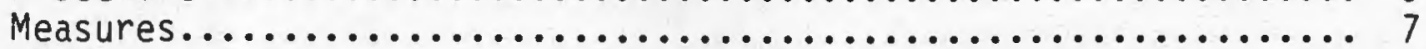

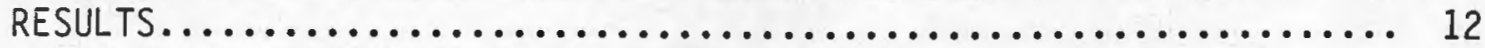

FRI Component Structure Results....................... 12

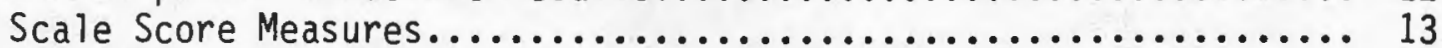

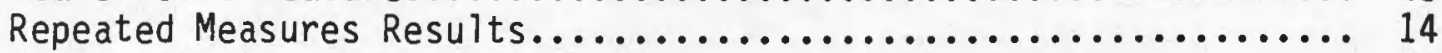

Independent T-Test Results.......................... 16

Structural Model Results............................. 16

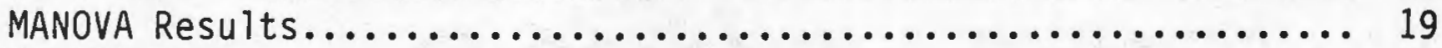

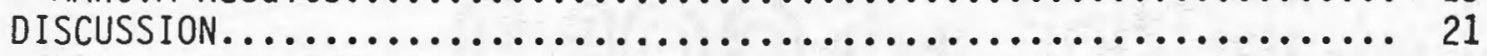

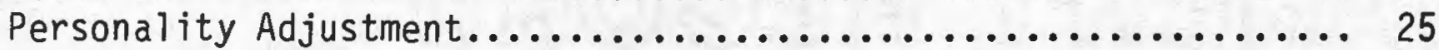

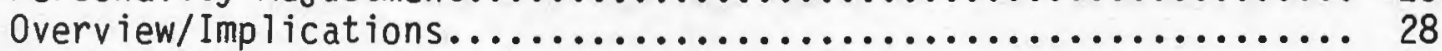

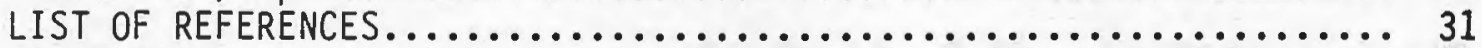

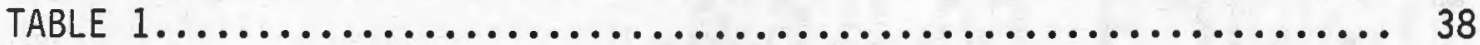

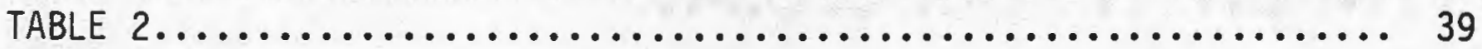

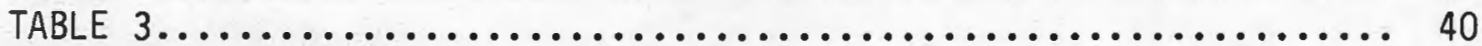

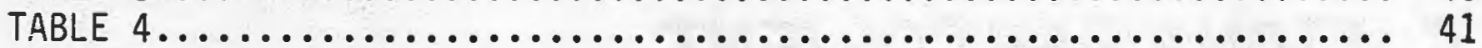

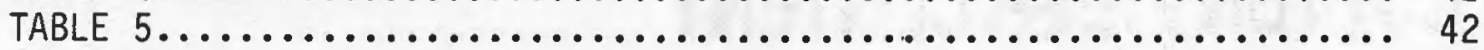

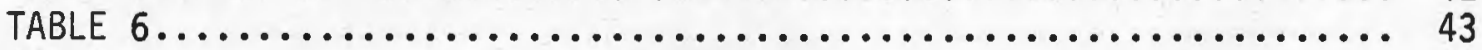

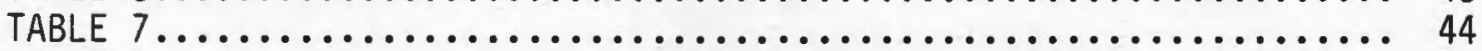

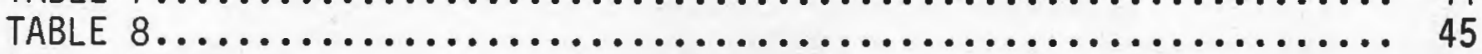

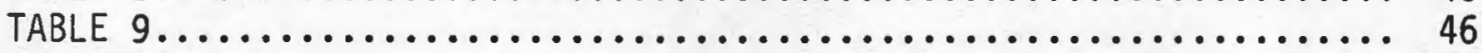

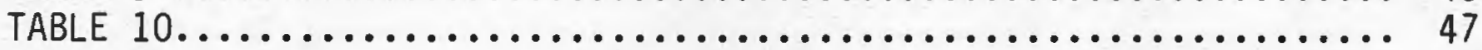

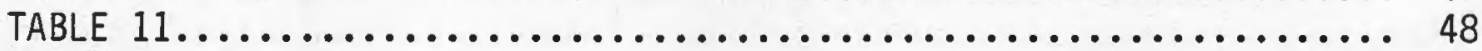

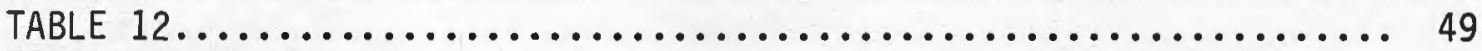

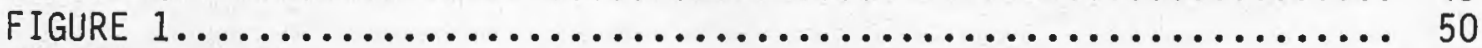

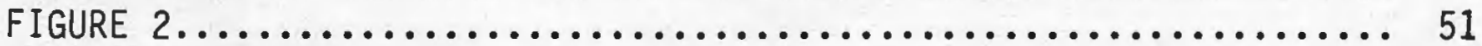

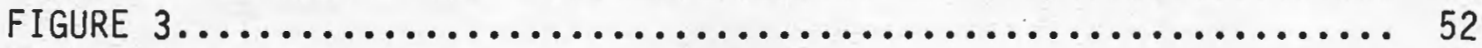

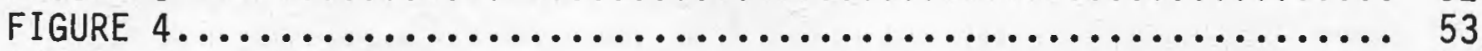

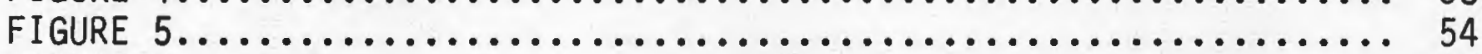

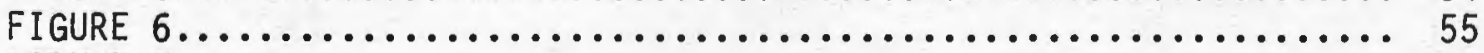

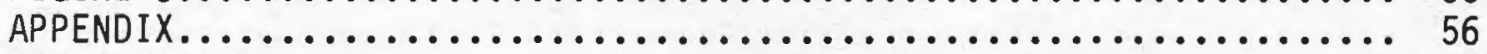

BIBLIOGRAPHY ..................................... 89 


\section{LIST OF TABLES}

1. FRI FATHER NURTURANCE ITEMS $\ldots \ldots \ldots \ldots \ldots \ldots \ldots \ldots \ldots \ldots \ldots \ldots \ldots \ldots \ldots$

2. FRI father ACCEPTANCE ITEMS $\ldots \ldots \ldots \ldots \ldots \ldots \ldots \ldots \ldots \ldots \ldots \ldots \ldots \ldots \ldots \ldots$

3. FRI MOTHER NURTURANCE ITEMS $\ldots \ldots \ldots \ldots \ldots \ldots \ldots \ldots \ldots \ldots \ldots \ldots, 40$

4. FRI MOTHER ACCEPTANCE ITEMS $\ldots \ldots \ldots \ldots \ldots \ldots \ldots \ldots \ldots \ldots \ldots \ldots \ldots \ldots \ldots$

5. SCALE SCORES FOR EIGHT FRI SCALES $\ldots \ldots \ldots \ldots \ldots \ldots \ldots \ldots \ldots \ldots . \ldots \ldots$

6. PEARSON PRODUCT-MOMENT CORRELATION COEFFICIENTS

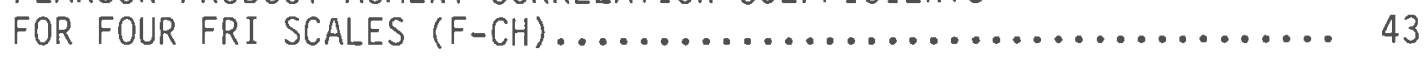

7. PEARSON PRODUCT-MOMENT CORRELATION COEFFICIENTS

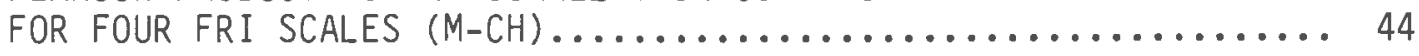

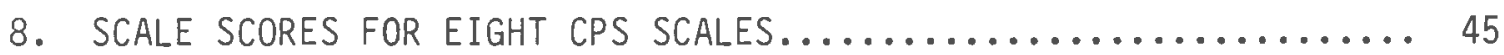

9. PEARSON PRODUCT-MOMENT CORRELATION COEFFICIENTS

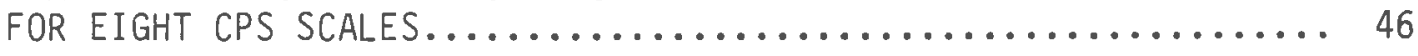

10. SCALE SCORES FOR SIXTEEN FRI SUB-SCALES............... 47

11. MEANS, STANDARD DEVIATIONS, F RATIOS, AND EFFECT SIZE FOR FOLLOW-UP ANOVAS (FNUR) $\ldots \ldots \ldots \ldots \ldots \ldots \ldots \ldots \ldots \ldots, 48$

12. MEANS, STANDARD DEVIATIONS, F RATIOS, AND EFFECT SIZE FOR FOLLOW-UP ANOVAS (GENDER) .................... 49 
We have become increasingly aware of the importance of the fatherchild relationship in what Lamb (1979) has termed "an era of paternal rediscovery". Numerous studies suggest that from early in infancy fathers are at least as important as mothers in their influence on the social development and cognitive functioning of their children (Biller \& Meredith, 1974; Biller \& Solomon, 1986; Lamb, 1978, 1981; Parke, 1979). Moreover, there is much evidence indicating that positive father-child involvement can greatly facilitate the child's cognitive and social competence at various stages of development, whereas paternal deprivation can have a significantly detrimental impact (Biller, 1971, 1974; Biller \& Solomon, 1986; Radin, 1981).

\section{Fathers and Sons}

Early research concerning the impact of the fathering role on sons' development focused on the area of masculine sex-role learning. In general, studies have suggested that a young boy's masculine self-image is related to the strength of his identification with his father (Biller, 1971; Heilbrun, 1974; Mussen \& Distler, 1959; Payne \& Mussen, 1956). Moreover, it has been shown that sons' identification with fathers is significantly facilitated by paternal attributes of warmth, acceptance and nurturance (Biller, 1969; Mussen \& Rutherford, 1963; Payne \& Mussen, 1956; Sears, 1953).

Subsequent research examining the impact of father-son interaction on sons' cognitive development and academic achievement has yielded findings suggestive of a positive relationship between paternal acceptance 
and nurturance received and greater cognitive competence and school achievement in both pre-adolescent and adolescent boys (Biller, 1974; Blanchard \& Biller, 1971; Lynn, 1974; Radin, 1972, 1976, 1981).

Research assessing the father-son relationship relative to sons' personality adjustment has generated similar results pointing to a consistent, positive relationship between degree of paternal acceptance and nurturance received and personality adjustment in sons at various stages of development (Bergenstal, 1981; Biller, 1971, 1974; Block, 1971; Sears, 1970). In studies examining paternal influence on sons' self-concept, a strong association between positive father involvement and healthy self-esteem in sons has been reported (Coopersmith, 1967; Medinnus, 1965; Sears, 1970). Research by Rosenberg (1965) also suggests that early father-son interaction may be especially influential in the development of the child's self-concept.

Studying college males, Reuter \& Biller (1973) reported that subjects who experienced a combination of at least moderate paternal nurturance and at least moderate paternal availability scored higher on measures of personal adjustment than those whose fathers were low in either or both nurturance and availability. Block (1971) found that males who were well adjusted in adulthood had fathers as well as mothers who were highly nurturant and involved in their upbringing. Block, von der Lipp, and Block (1973) reported similar findings suggestive of a relationship between positive paternal involvement and healthy personality adjustment in adult males. 
Fathers and Daughters

Although most of the research examining paternal influence and the child's social development and cognitive functioning has focused on the father-son relationship, father-daughter interaction has also been investigated. Similar to father-son studies, research concerning the father-daughter relationship has generally been supportive of paternal influence. There is a considerable amount of data indicating that fathers have a significant impact on their daughter's cognitive and social competence throughout childhood and adolescence (Baumrind \& Black, 1967; Block, 1971; Radin, 1981; Torgoff \& Dreyer, 1961).

Fathers appear to have an especially influential role relative to daughters' sex-role development (Biller \& Solomon, 1986; Heilbrun 1965; Hetherington, Cox and Cox, 1982; Johnson, 1963; Mussen \& Rutherford, 1963). Indeed, there is some evidence suggesting that fathers are more concerned about sex differences than mothers and thus exert greater influence on daughters' as well as sons' sex-role learning (Aberle \& Naegele, 1952; Biller, 1974; Brofenbrenner, 1961; Goodenough, 1957; Lamb, 1976; Rothbart \& Maccoby, 1966). Moreover, the presence of a positively involved, nurturant father can significantly enhance a daughter's positive, healthy view of her femininity (Hetherington, Cox, and Cox, 1978, 1982).

Fathers can have a substantial impact on their daughters' cognitive functioning as well (Bieri, 1960; Plank \& Plank, 1954). High paternal nurturance, when combined with positive expectations for competence, has been found to be positively related to daughters' cognitive competence 
and academic success especially in adolescence and adulthood (Biller \& Solomon, 1986; Crandall, et al., 1964; Radin, 1981).

Research concerning paternal influence and daughters' personal and social adjustment have also been supportive of the importance of positive father involvement (Baumrind \& Black, 1967; Biller \& Weiss, 1970; Torgoff \& Dreyer, 1961). In a study of college females, Fish and Biller (1973) reported that the father may have a particularly significant impact on girls' personality adjustment. Subjects who perceived their fathers as being very nurturant and accepting of them scored high on the Adjective Checklist Personal Adjustment Scale. Conversely, those who perceived their fathers as having been rejecting scored quite low on the personal adjustment scale.

In a related study, Block (1971) found that adult females who scored highest on measures of personal adjustment were those who reported having experienced two positively involved parents. The importance of both a nurturant, accepting father and a positively involved mother in girls' personality adjustment has been supported in other investigations as well (Block, 1973; Block, von der Lipp, and Block, 1973; Huckel, 1984). Most notably, Huckel (1984) found that college females who had both a nurturant and accepting father and mother scored high on measures of self-confidence, emotional stability, and social competence.

\section{Summary}

A review of the principal literature concerning the role of fatherchild interaction in children's psychological and social functioning 
suggests that fathers have a significant impact on the development of both sons and daughters, especially in the areas of early sex-role learning, cognitive competence and achievement, and personality adjustment. Nonetheless, there is little empirical information regarding the impact of the father-child relationship on sons' and daughters' functioning in adulthood, and particularly the task of parenting.

A major objective of the present study was to investigate the interrelationships between parents' and children's perceptions of the quality of fathering received. Participating students and their parents each completed measures of their perceptions of paternal acceptance and nurturance. Intercorrelations between students' and parents' perceived parental nurturance and acceptance were examined through the utilization of a structural equation model. 
METHOD

Subjects

Two-hundred and fifty (250) undergraduate students (126 males and 124 females), enrolled in psychology classes at three area colleges, the University of Rhode Island, Roger Williams College, and the Community College of Rhode Island, and their parents served as subjects in the study. Thus, a total of 750 persons are included in the study.

In the selection of participants for the study, a major concern was to obtain a relatively large number of subjects which would make certain statistical analyses possible. Based on availability, the subject population employed was relatively homogeneous. All subjects were white, middle class, and from intact families.

The total sample of students ranged in age from 18-24 with a mean age of $20.1(S D=1.5)$. The age range for sons was $18-24$ with a mean age of $20.4(S D=1.6)$, whereas daughters ranged in age from 18-23 with a mean age of $19.8(S D=1.4)$. Participating parents were between 38-70 years of age with a mean age of $48.2(S D=5.8)$. Fathers ranged in age from 39-70 with a mean age of $49.5(S D=6.1)$, whereas the age range for mothers was 38-68 with a mean age of $46.8(S D=5.4)$.

\section{Procedure}

Each subject in the study completed a single 10-page questionnaire consisting of two parts. Part 1 is an abbreviated version of the Family Data Form (FDF) and part 2 is comprised of items from the Family Relations Inventory (FRI). This questionnaire was utilized for both stu- 
dents and their parents. In addition, students completed the Comrey Personality Scales (CPS).

Students were solicited during regularly scheduled class meetings and received extra credit points for their own participation and that of their parents. Questionnaires were mailed home to parents who returned them in completed form to the examiner.

\section{Measures}

The Family Data Form (FDF), developed by Huckel (1984), was used to obtain individual and family demographic information from each subject. An abbreviated version of the FDF, consisting of 10 items, was utilized in the present study.

The Family Relations Inventory (FRI), originally developed by Brunkan \& Crites (1964), and later analyzed psychometrically for component structure by Huckel (1984), was used to assess subjects' perceptions of the quality of parenting received. The original FRI consists of 202 true-false items, each measuring a specific parental behavior. The instrument yields six scale scores, representing three parental attitudes (Acceptance, Avoidance, Concentration) associated with both mothers and fathers. Reliability and validity estimates for the original scale are satisfactory and are reported by Huckel (1984).

The basis of Huckel's (1984) work was to assess the FRI's component structure, since there had not been any previous studies of this nature, and to develop an empirically based procedure for scoring. Four experimentally derived scales were identified by Huckel (1984) constituting 
measures of the following: a) Father Acceptance, b) Father Nurturance, c) Mother Acceptance, and d) Mother Nurturance.

Nurturance scales measure the degree of perceived Nurturance vs. Neglect (parental involvement, encouragement, support) characterizing subjects' parental relationships during childhood and adolesence. Acceptance scales measure the degree of perceived Acceptance vs. Rejection (parental approval, affirmation, understanding) characterizing subjects' parental relationships during childhood and adolescence.

The obtained components were shown to have adequate internal consistency (Huckel, 1984). Alpha coefficients computed for each of the four scales ranged from .81 to .88. Pearson product-moment correlation coefficients calculated among scales ranged from .24 to .53, suggesting moderate to substantial relationships among the four scales.

In the present investigation, principal components analyses were conducted to verify Huckel's (1984) interpretation of the FRI's component structure. Obtained results suggested a factor structure consistent with Huckel's (1984) findings for both FRI-Father and FRIMother items. A more stringent selection criterion was employed, resulting in 10 items being retained for each measure of parental involvement. Component structure analyses and the criterion for item selection are further described in the Results Section.

The present study utilized the four derived FRI scales, each consisting of 10 items, to assess subjects' perceptions of paternal and maternal acceptance and nurturance received. The refined Father Nurturance Scale consists of 4 positively stated items reflecting pater- 
nal concern, availability, and reliability, and 6 negatively worded items associated with paternal disinterest, unreliability, and neglect. Father Nurturance items are found in Table 1 (page 38).

The derived Father Acceptance measure consists of 5 positively worded items reflecting paternal understanding, approval, and respectful valuing, and 5 negatively phrased items describing paternal behaviors characteristic of a general lack of communication, approval, and understanding. Father Acceptance items are found in Table 2 (page 39).

Mother involvement scales were also employed to assess interrelationships between mothers' perceived paternal involvement and childrens' perceptions of maternal involvement. The 10-item Mother Acceptance measure is very similar to Father Acceptance in terms of item content and general tone. This scale consists of 9 positively stated items and 1 negatively worded item, reflecting an overall theme of maternal understanding, approval, and positive valuing. Mother Acceptance items are found in Table 3 (page 40).

The refined Mother Nurturance scale is also similar to its FRI-Father counterpart relative to content and general theme. Comprised exclusively of negatively phrased items, it describes behaviors associated with parental disinterest and unavailability. This scale differs from the Father Nurturance measure in that it includes items more strongly reflective of physical and emotional neglect. Mother Nurturance items are found in Table 4 (page 41).

Subjects were instructed to rate each item on a 6-point scale ranging from "strongly disagree" to "strongly agree" ( 1 = strongly 
disagree 2 = disagree, 3 = disagree somewhat, 4 = agree somewhat, $5=$ agree, 6 = strongly agree). A sample questionnaire is provided in the Appendix.

The Comrey Personality Scales (CPS) developed by Comrey (1970) was utilized to provide a measure of students' personality adjustment. The CPS yields eight scale scores, each measuring a specific personality dimension. The eight personality scales are as follows: Trust vs. Defensiveness ( $T$ ), Orderliness vs. Lack of Compulsion ( 0 ), Social Conformity vs. Rebelliousness (C), Activity vs. Lack of Energy (A), Emotional Stability vs. Neuroticism (S), Extraversion vs. Intraversion (E), Masculinity vs. Femininity (M), and Empathy vs. Egocentrism (P). Each scale consists of twenty items, four items in each of 5 FHID's (Factored Homogeneous Item Dimensions). Within each FHID, two items are positively worded and two items are negatively worded. In addition, there are two validity scales, the Validity Check ( $V$ ) scale which has eight items, and the Response Bias ( $R$ ) scale consisting of twelve items, for a total of 180 items in the entire inventory.

CPS scales and item dimensions comprising each scale are as follows: Trust vs. Defensiveness (Lack of Cynicism, Lack of Defensiveness, Belief in Human Worth, Trust in Human Nature, and Lack of Paranoia); Orderliness vs. Lack of Compulsion (Neatness, Routine, Order, Cautiousness, and Meticulousness); Social Conformity vs. Rebelliousness (Law enforcement, Acceptance of the Social Order, Intolerance of Non-Conformity, Respect for Law, and Need for Approval); Activity vs. Lack of Energy (Exercise, Energy, Need to Excel, Liking for Work, and Stamina); Emotional Stability 
vs. Neuroticism (Lack of Inferiority Feelings, Lack of Depression, Lack of Agitation, Lack of Pessimism, and Mood Stability); Extraversion vs. Introversion (Lack of Reserve, Lack of Seclusiveness, No Loss for Words, Lack of Shyness, No Stage Fright); Masculinity vs. Feminity (No Fear of Bugs, No Crying, No Romantic Love, Tolerance of Blood, and Tolerance of Vulgarity); Empathy vs. Egocentrism (Sympathy, Helpfulness, Service, Generosity, and Unselfishness).

Reliability estimates for the CPS are favorable (Comrey, 1970). To obtain reliability estimates, Comrey, using a sample of 746 volunteer subjects, divided the items in each scale into two equivalent halves by randomly choosing one positively worded and one negatively worded item from each FHID defining that factor, yielding ten items for each half scale. The two halves were correlated and the coefficients corrected to full-test reliabilities through utilization of the Spearman-Brown formula. Reliability coefficients ranged from .87 to .96 for the eight personality scales.

Studies concerning the validity of the CPS have yielded favorable results. The CPS has been shown to have satisfactory factorial (Comrey, 1970) and construct (Comrey and Backer, 1970) validity. In addition, Comrey (1970) and Comrey and Backer (1970) have found that the underlying structure of the CPS compares favorably with the factor systems of Guilford (1954), Cattell (1965), and Eysenck (1964).

The present study utilized all eight personality scales, each consisting of 20 items, to provide a measure of students' personality adjustment. CPS items can be found in the Appendix. Items are listed 
by scale and grouped according to the FHID's associated with each of the eight scales. Items comprising each of the two validity scales are also found in the Appendix.

The CPS employs a 7-point Likert scale format with two separate response option scales. Subjects were instructed to use Scale $X$ or Scale $Y$ in responding to test items. Scale $X$ responses range from 1 ) never to 7 ) always $(1=$ never, 2 = very rarely, $3=$ rarely, $4=$ occasionally, $5=$ frequently, $6=$ very frequently, $7=$ always ) and Scale $Y$ responses range from 1 ) definitely not to 7 ) definitely ( 1 = definitely not, 2 = very probably not, $3=$ probably not, $4=$ possibly, $5=$ probably, 6 = very probably, 7 = definitely). A sample questionnaire is provided in the Appendix.

\section{RESULTS}

\section{FRI Component Structure Results}

Three subject groups (students, fathers, mothers), each consisting of 250 persons, were utilized and independent principal components analyses were conducted on intercorrelation matrices calculated for the 40 FRI-Father items and the 40 FRI-Mother items. Velicer's (1976; Zwick \& Velicer, 1982) Minimum Average Partial Correlation (MAP) criterion was employed to determine the number of components retained and a Varimax rotation was then performed on the resulting component patterns. Items yielding a factor loading of .40 or greater across the three subject groups were retained, whereas, items characterized by complex or insufficient loadings were eliminated. 
Principal components analyses computed for the $40 \times 40$ matrices of intercorrelations calculated for FRI-Father items yielded two components for each subject group. Obtained components accounted for $36 \%$ of the total variance when students were tested, $42 \%$ for the sample of fathers, and $46 \%$ for mothers participating in the study. Components derived in the present analyses are consistent with factors identified by Huckel (1984), namely, Father Nurturance and Father Acceptance. Based on the aforementioned selection criterion, 10 items related to paternal nurturance and 10 items related to paternal acceptance were retained for further investigation in the current study. Selected items related to Father Nurturance are found in Table 1 (page 38), whereas, Father Acceptance items are found in Table 2 (page 39).

Principal components analyses conducted on the $40 \times 40$ matrices of intercorrelations computed for FRI-Mother items also yielded two components for each subject group. Derived components accounted for $35 \%$ of the total variance for students, $37 \%$ for fathers, and $45 \%$ for mothers, and were consistent with factors identified by Huckel (1984). Based on the cut-off criterion utilized, 10 items related to maternal nurturance and 10 items related to maternal acceptance were selected for further analyses in the present investigation. Retained items related to Mother Nurturance are found in Table 3 (page 40) whereas, Mother Acceptance items are found in Table 4 (page 41).

\section{Scale Score Measures}

Scale score measures were obtained for each of the 10-item parental involvement scales utilized in the study. Means, standard deviations, 
and coefficient alphas for each scale are presented in Table 5 (page 42). In general, the scales were shown to have satisfactory internal consistency as alpha coefficients ranged from .72 to .87 . Pearson product-moment correlation coefficients were also computed among scales. Correlation coefficients for measures of paternal involvement employed in analyses of fathers and children are found in Table 6 (page 43), whereas correlation coefficients for scales utilized in analyses of mothers and children are reported in Table 7 (page 44).

Scale score measures were also determined for each of the eight CPS scales. Means, standard deviations, and coefficient alphas for each scale are presented in Table 8 (page 45). Estimates of internal consistency were satisfactory as alpha coefficients ranged from .76 to .90 . Pearson product-moment correlation coefficients among scales are reported in Table 9 (page 46).

\section{Repeated Measures Results}

Fathers and children were treated as matched pairs and two repeated measures analyses were completed to compare the amounts of paternal nurturance and acceptance reported by fathers and children. Similar analyses were computed for fathers vs. sons, and fathers vs. daughters.

Results of the analyses yielded significant differences between fathers and children for both the degree of nurturance and acceptance reported. Children rated their perceived nurturance higher, with a mean rating for children of 5.08 compared to a mean of 4.63 for fathers ( $t=$ $7.00, d f=249,(.001)$. 
Significant differences between fathers' and sons' reports of paternal nurturance and acceptance were also found. Sons reported higher perceived nurturance, with a mean rating for sons of 4.93 compared to a mean of 4.59 for fathers $(t=3.51, d f=125, p<.001)$. Sons also reported greater paternal acceptance received relative to fathers. Sons had a mean rating of 3.52 compared to a mean of 3.17 for fathers ( $t=$ $3.41, d f=125, p(.001)$.

Similar results were found when fathers' and daughters' perceptions of paternal involvement were compared. Daughters rated their perceived nurturance higher, with a mean of 5.22 , compared to a mean of 4.66 for fathers $(t=6.75, d f=123, p<.001)$. Daughters' perceptions of paternal acceptance were higher as well. A mean rating of 3.61 was found for daughters compared to a mean of 3.15 for fathers $(t=4.40$, df $=123, p<.001$ ).

Mothers' and children's reports of paternal involvement were also compared. Children reported higher paternal nurturance, with a mean rating for children of 5.08 compared to a mean of 4.68 for mothers ( $t=$ 5.29, $d f=249, p<.001)$. Greater paternal acceptance was reported by children as well, with a mean of 3.57 for children compared to a mean of 3.05 for mothers $(t=6.35, d f=249, p<.001)$.

Sons' perceived nurturance was rated higher, with a mean rating for sons of 4.93 compared to a mean of 4.65 for mothers $(t=2.79, \mathrm{df}=125$, $p<.01)$. Sons reported greater paternal acceptance, with a mean of 3.52 for sons compared to a mean of 3.09 for mothers $(t=4.13$, df $=125$, $p<.001)$. 
Daughters reported greater paternal nurturance relative to mothers, with a mean rating for daughters of 5.22 compared to a mean of 4.71 for mothers $(t=4.65, d f=123, p<.001)$. Similar results were found for paternal acceptance, with a mean of 3.61 for daughters compared to a mean of 3.01 for mothers $(t=4.82, d f=123, p<.001)$.

\section{Independent T-Test Results}

Independent t-tests were conducted to compare the amounts of parental nurturance and acceptance reported by daughters and sons. Daughters reported greater paternal nurturance relative to sons, with a mean rating for daughters of 5.22 compared to a mean of 4.93 for sons ( $t=$ 3.50, $d f=248, p<.001)$. Daughters' perceived maternal nurturance was also rated higher, with a mean of 5.37 for daughters compared to a mean of 5.19 for sons $(t=2.32, d f=248, p<.05)$. No significant differences were found between sons and daughters on the parental acceptance scales.

\section{Structural Model Results}

Six separate structural equation models were employed to assess interrelationships between parents' and children's perceptions of paternal involvement. In each case, parental involvement scales were divided into two 5-item component sub-scales in order to provide multiple indicators for the constructs of acceptance and nurturance. Scale score measures were computed for sub-scales and are basically consistent with means, standard deviations, and coefficient alphas for the scales. Subscale measures are reported in Table 10 (page 47). 
The model utilized to examine the relationship between fathers' and children's perceptions of paternal involvement is presented in Figure 1 (page 58). The computer program LISREL VI (Joreskog \& Sorbom, 1984) waS utilized for data analysis. Four separate path coefficients were obtained and subsequently tested for significance. Path coefficients were obtained for the following pairs of variables: 1) fathers' paternal nurturance received to children's paternal nurturance received, 2) father's paternal acceptance received to children's paternal acceptance received, 3) fathers' paternal nurturance received to children's paternal acceptance received, and 4) fathers' paternal acceptance received to children's paternal nurturance received. Of the four path parameter estimates, only 1) fathers' paternal nurturance received to children's paternal nurturance received was found to be significant. Path parameter estimates are found in Figure 1 (page 50). All factor loadings were significant, ranging from .80 to .91 .

Correlations between fathers' reported acceptance and nurturance and children's perceived acceptance and nurturance, respectively, were also calculated to assess relationships between these constructs. Obtained correlation coefficients can be found in Figure 1 (page 50). The structural model was then tested for overall goodness of fit. The model seemed to fit adequately with a chi-square $=23.57$, df $=14, p<.06$, a goodness of fit index of .98 , and a root mean square residual of .03 .

The relationship between paternal acceptance and nurturance reported by fathers and sons was investigated using the model presented in Figure 2 (page 51). Similar to findings reported previously, only one of four 
path parameter estimates, namely, fathers' perceived paternal nurturance to sons' perceived paternal nurturance, was found to be significant. These path parameter estimates can be found in Figure 2 (page 51). All factor loadings were significant, ranging from .80 to .95 . Correlation coefficents for fathers' reported acceptance and nurturance received and sons' perceived acceptance and nurturance, respectively, are also found in Figure 2 (page 51). The structural equation model seemed to fit adequately with a chi-square $=25.19, \mathrm{df}=14, \mathrm{p}<.04$, a goodness of fit index of .95 , and a root mean square residual of .05 .

The relationship of father-daughter interaction and perceived paternal involvement was evaluated using the model presented in Figure 3 (page 52). Consistent with previously reported results, only one of four path parameter estimates, namely, fathers' perceived paternal nurturance to daughters' perceived paternal nurturance, was found to be significant. Path parameter estimates can be found in Figure 3 (page 52). All factor loadings were significant, ranging from .78 to .94 . Correlation coefficents relative to fathers' reported acceptance and nurturance and daughters' reported acceptance and nurturance, respectively, are found in Figure 3 (page 53) as well. The structural equation model appeared to fit adequately with a chi-square $=8.49$, df $=$ $14, p<.90$, a goodness of fit index of .98 , and a root mean square residual of .03 .

The relationship of mothers' and children's perceived paternal involvement was also investigated. For the total sample of mothers and children, the model depicted in Figure 4 (page 53) was utilized. Models 
employed to assess relationships between mothers' and sons', and mothers' and daughters' reports of paternal acceptance and nurturance are presented in Figure 5 (page 54) and in Figure 6 (page 55) respectively.

In each case, structural model analyses yielded no significant findings for interrelationships between mothers' perceived paternal involvement and children's perceptions of maternal involvement. Path parameter estimates were consistently low across models and are included in the figure associated with each model. Factor loadings pertaining to each model were significant, ranging from .78 to .98. Correlation coefficients were also obtained for relationships between paternal acceptance and nurturance as reported by mothers and children, respectively. These estimates are provided in each figure depicting one of the af: mentioned models. All structural equation models appeared to fit adequately. Chi-square estimates were nonsignificant for each model. Goodness of $\mathrm{fit}$ indices ranged from .96 to .99 , whereas root mean square residuals ranged from .02 to .04 .

MANOVA Results

The relationship of perceived paternal involvement and sons' and daughters' personality adjustment was also investigated. The subject population for each measure of paternal involvement was divided into a high and low group of relatively equal size based on a median split. Multivariate analyses of variance were computed to assess relationships between subjects' reports of paternal acceptance and nurturance 
received, respectively, and the eight personality scales as a function of sex. Degree of paternal involvement (high vs. low) and gender (male vs. female) are the independent variables in this portion of the study, whereas, the eight personality scales represent the dependent variables.

When paternal acceptance was employed as a measure of father involvement, the overall MANOVA was not found to be significant. A significant MANOVA result was found when paternal nurturance was utilized as a measure of father involvement (Wilks lambda $=.94, F(8,238)=$ 2.05, $\left.p<.05, R^{2}=.06\right)$. No significant interaction between paternal nurturance and gender was present.

A significant main effect for paternal nurturance was found, $F\left(8,238^{\circ}\right.$ $=3.40, p<.01, R^{2}=.10$. Degree of paternal nurturance was significantly related to three of the eight personality scales, namely, Social Conformity vs. Rebelliousness (C), Emotional Stability vs. Neuroticism $(S)$, and Extraversion vs. Introversion (E). Subjects reporting greater paternal nurturance scored higher on measures of social conformity, emotional stability, and extraversion relative to subjects reporting lower paternal nurturance. There were no significant sex differences relative to these scales. Means, standard deviations, $F$ ratios, and indices of effect size for the follow-up ANOVAS are reported in Table 11 (page 48). A significant main effect was also found for sex when the paternal nurturance measure was employed, $F(8,238)=21.65, p<.001, R^{2}=.42$. Gender was significantly related to the following four personality measures; Trust vs. Defensiveness (T), Activity vs. Lack of Energy (A), Masculinity vs. Femininity (M), and Empathy vs. Egocentrism (P). Females 
scored higher on the $(T)$ and $(P)$ scales, indicating greater levels of empathy and trust relative to male subjects, whereas, males had higher scores on the $(A)$ and $(M)$ scales, indicating a relatively higher degree of masculinity and activity level compared to female subjects. Means, standard deviations, F ratios, and indices of effect size for these follow-up ANOVAS are reported in Table 12 (page 49).

\section{DISCUSSION}

Based on previous research supportive of a significant relationship between positive paternal involvement and children's more competent psychological and social functioning during childhood and adolescence, it was anticipated that results of the present study would be suggestive of positive intercorrelations between parents' and children's perceptions of paternal nurturance and acceptance. This hypothes is received some support in the present study. Fathers' perceived paternal nurturance was shown to relate significantly to children's reports of paternal nurturance received, whereas, parents' perceived paternal acceptance was not found to be significantly related to children's perceptions of paternal acceptance across all subject groups.

It should be noted that although the sample employed in the study was large enough to permit certain statistical analyses of the data, there was not much variability of scores on the FRI scales. Subjects were generally from families in which there was a strong degree of parental involvement. This was particularly evident in the case of stu- 
dents who as a whole reported relatively high amounts of parental nurturance. Parental support was also evidenced by parents' willingness to participate in the study by filling out questionnaires. With a more representative sample and greater variability of scores on the parental involvement scales, results of the present investigation would probably have been more strongly supportive of paternal influence.

Despite the limitations of the sample tested, there are positive implications for this group of subjects. Indeed, there is appreciable support for a strong degree of parental involvement for the population sampled. Relatively high levels of perceived paternal and maternal nurturance were reported across all subject groups participating in the study.

The paternal nurturance factor was show to be particularly influential. Path parameter estimates obtained for fathers' perceived paternal nurturance and the perceptions of father nurturance reported by the total sample of children, sons, and daughters, respectively, were all shown to be significant.

Although fathers' perceived paternal nurturance was found to be related to both sons' and daughters' perceived father nurturance, a similar relationship was not found for perceived acceptance. Crosscorrelations between fathers' perceptions of paternal nurturance and paternal acceptance reported by the total sample of children, sons, and daughters, respectively, were not shown to be significant.

of particular interest at the cross-correlational level is the finding of a significant negative correlational coefficient value for 
fathers' perceived paternal acceptance and sons' reported paternal nurturance. The suggestion of an inverse relationship between these two constructs was not expected. One possible explanation is that a compensatory factor is influencing this result. It may be that fathers who receive low paternal acceptance desire to compensate for this by exhibiting greater nurturance toward their sons. This appears to have more relevance for father-son relationships as compared to father-daughter interaction. Although the obtained correlational coefficient value for the latter relationship was also negative, it was relatively low and not of statistical significance. These suggestions are speculative given the exploratory nature of this study.

Another interesting finding is that mothers' perceived paternal involvement was not shown to be significantly related to children's ceptions of maternal involvement. Correlations between mothers' paternal nurturance received and maternal nurturance reported by the total sample of children, daughters, and sons, respectively, were consistently low, with no path parameter estimates reaching a level of statistical significance.

The suggestion that mothers' perceived paternal involvement may not be highly related to children's perceptions of mother involvement is somewhat surprising. Previous studies focusing on father-daughter interaction have generally been supportive of the father's influential role relative to daughters' development throughout childhood, adolescence, and into early adulthood, particularly in the area of personality adjustment (Block, 1971; Fish \& Biller, 1973; Huckel, 1984). 
In any event, the present results appear to suggest that what aduit sons report about the quality of fathering received may have a greater influence on their children's perceptions of parental involvement as compared to what is reported by adult daughters.

It is also interesting to note that although structural equation models employed in the study were generally shown to have adequate goodness of fit relative to the data, the variables tested did not account for much of the variance. With the exception of the paternal nurturance factor, obtained path parameter estimates were relatively low, while prediction of error values (refer to figures) were generaliy high. Paternal involvement has some influence, particularly in the case of adult sons, yet variables other than what parents experience from their fathers are impacting on children's perceptions of the quality of parenting received.

Children's perceived parental involvement may be influenced by such intervening variables as the child's own personality attributes or the degree of perceived involvement on the part of other family members. Family system factors such as the nature of the parents' relationship and the functioning of the family unit as a whole may also be exerting some influence. These factors may be useful to investigate in future studies. In any event, there is an important need for more extensive research concerning the interrelationships of parents' and children's perceptions of parental involvement. 
Personality Adjustment

An assessment of the relationship between perceived paternal involvement and the late adolescent's personality adjustment revealed that paternal involvement was related to some measures of personality functioning. Paternal nurturance was shown to be significantly related to subjects' personality adjustment, but no significant findings were obtained relative to the relationship of paternal acceptance and the personality adjustment measures.

Due to the relative homogeneity of the subject group tested, reported levels of paternal involvement were skewed toward the higher end of each scale. Therefore, group differences may in fact be comparisons of relatively high vs. moderate amounts of perceived paternal involvement, particularly in the case of father nurturance. It is relevant to point out that what is considered low nurturance in the present study is comparable to moderate nurturance in at least some previous studies concerning paternal involvement (Huckel, 1984; Reuter \& Biller, 1973). Moreover, in the Reuter \& Biller (1973) study of college males, a moderate level of perceived paternal nurturance, when combined with at least moderate father availability, was shown to relate to subjects' positive personality adjustment.

In the present study, few scores were within the lower ranges of paternal involvement. With greater variability of scores, a more meaningful group comparison of subjects' reporting high vs. Tow levels of paternal involvement would have been possible. It is interesting to 
note that when extreme scores were considered, subjects who scored very highly on both paternal involvement scales consistently had high scores on the personality adjustment measures, whereas, subjects reporting very low levels of paternal involvement tended to have lower scores on the measures of personality adjustment.

The influential nature of paternal nurturance relative to subjects' functioning in adolescence and adulthood was established throughout this study. Thus, there is some indication that paternal nurturance may be a particularly meaningful measure of father involvement for this subject population. This suggestion has received support in earlier studies indicating a positive relationship between paternal nurturance received and healthy personality adjustment in college students (Reuter \& Biller, 1973) and in adult subjects (Block, von der Lipp, and Block, 1973).

In the present study, analyses of relationships between paternal nurturance and various measures of personality adjustment revealed that nurturant paternal involvement was positively related to students' selfreports of emotional stability, social adjustment, and general confidence in social situations. These findings suggest that early paternal involvement may have a greater impact on those aspects of the individual's later personality adjustment specifically related to social competency. Previous studies have revealed a similar relationship between positive father involvement and indicators of high sociability and competent social functioning in adolescents (Block, 1971, 1973; Huckel, 1984) and young adults (Block, 1971; Block, von der Lipp, and Block, 1973). 
There were no statistically significant gender differences for the personality measures found to be related to paternal involvement. Thus, it appears that nurturant fathering behavior can have an appreciable impact on the positive social adjustment of both adolescent sons and daughters. This finding has been supported by earlier research indicative of enhanced social adjustment for both male and female adolescents who had the experience of an involved, nurturant father (Block, 1971, 1973; Radin, 1981).

Significant gender differences were obtained on certain scales. Females scored higher on measures of basic trust in human nature and helpfulness, whereas, males scored higher on measures of masculinity and general activity, regardless of what measure of paternal involvement was employed in the analyses.

A somewhat suprising finding is the absence of statistically significant relationships between father involvement measures and the Masculinity vs. Femininity personality scale. There are some studies which have been suggestive of a relationship between paternal involvement and relatively successful sex-role learning in both males (Biller, 1969, 1971; Heilbrun, 1974; Mussen, 1961; Payne \& Mussen, 1956), and females (Biller, 1974; Hetherington, Cox, and Cox, 1978, 1982; Lamb, 1976), particularly during the period of early childhood. The data is less clear for paternal influence and later sex-role development. By late adolescence and early adulthood, most persons appear to be more strongly influenced by societal and peer expectations (Biller, 1971; Biller \& Solomon, 1986). 
One possible explanation for the lack of a significant relationship between father involvement and subjects' scores on the Masculinity vs. Femininity scale is the nature of the M-F measure employed in this study. Selected items defining masculinity and femininity were based on a rather limited conceptualization of these concepts. High scores on the scale are suggestive of masculinity and are characteristic of individuals who tend to be tough-minded, who are not bothered by blood, crawling creatures, or vulgarity, who do not cry easily, and who are disinterested in love stories. A low score on this scale is suggestive of femininity. It is apparent from this discussion that relatively high or low scores obtained on this scale are not necessarily indicative of healthy sex-role learning.

\section{Overview/Implications for Future Research}

The efficacy of early paternal influence relative to personality adjustment in late adolescence and adult sons' nurturance of their own children received some support in the present investigation. Although the sample employed did not yield a wide range of scores on the parental involvement measures, there are meaningful implications concerning the degree of parental involvement for this subject population. Relatively high levels of perceived father nurturance (involvement, availability, concern) were reported across all subject groups, whereas perceived paternal acceptance (approval, affirmation, understanding) was significantly lower. Strong paternal involvement is evident in the population sampled, yet the quality of father-child interaction could be enhanced. 
The data clearly suggests that fathers could be more accepting of their children.

Generational differences were also found in the present study. Students reported significantly greater paternal involvement than did their parents, suggesting that father involvement may be increasing from one generation to the next. Based on this data, it could be predicted that students themselves would tend to display even higher degrees of acceptance and nurturance toward their children. The need for longitudinal, intergenerational studies to explore this suggestion is apparent.

Future studies could also evaluate more heterogeneous populations in which greater variability of paternal involvement is present. With such a sample, more meaningful comparisons of groups reporting high vs. low levels of paternal acceptance and nurturance would be possible.

Research focusing on the developmental nature of the father-child relationship is also indicated. Specifically, longitudinal studies are needed to evaluate children's perceptions of paternal involvement and father-child interaction at different stages of development. In this way, a clearer understanding of the relative influence of father involvement on the child's functioning at various points throughout childhood, adolescence, and into adulthood might be gained. Reciprocity of father-child interaction at different life stages could also be explored.

Another possible direction for future research would be to examine the potential contribution of other variables which may be exerting an 
intervening influence on children's perceptions of paternal involvement. Relevant variables may include family system factors such as maternal influence, the nature of the parents' relationship, sibling relationships, the number and distribution of children in the family, and the child's specific birth order position in the family. Contact with other adult males and the influence of the child's peer group could also be explored.

Although the present study has yielded some information concerning the relationship of paternal involvement and sons' and daughters' functioning in late adolescence and adulthood, there are many questions still to be answered. The need for further research in this area is apparent. 


\section{LIST OF REFERENCES}

Aberle, D.F., \& Naegele, F.D. (1952). Middle-class fathers' occupational role and attitude toward children. American Journal of Orthopsychiatry, 22, 366-378.

Baumrind, D., \& Black. A.E. (1967). Socialization practices associated with dimensions of competence in preschool boys and girls. Child Development, 38, 291-327.

Bergenstal, Karl W. (1981). The relationship of father support and father availability to adolescent sons' experience of loneliness and separation anxiety. Dissertation Abstracts International, 42, 2024-B.

Bieri, J. (1960). Parental identification, acceptability, and authority, and within-sex differences in cognitive behavior. Journal of Abnormal and Social Psychology, 60, 76-79.

Biller, H.B. (1969). Father dominance and sex-role development in kindergarten age boys. Developmental Psychology, 1, 87-94.

Biller, H.B. Father, child, and sex-role. Lexington, Mass: Heath.

Biller, H.B., (1974). Paternal deprivation: Family, school, sexuality, and society. Lexington, Mass: Lexington Books, D.C. Heath and Company.

Biller, H.B. \& Meredith, D.L. (1974). Father power. New York: David Mckay, 1974; Reprinted, New York: Doubleday Anchor Books, 1975.

Biller, H.B. \& Weiss, S. (1970). The father-daughter relationship and the personality development of the female. Journal of Genetic Psychology, 114, 79-93.

Biller, H.B., \& Solomon, R.S. (1986). Child maltreatment and paternal deprivation: A minifesto for research, prevention, and treatment. Lexington, Mass: D.C. Heath and Company. 
Blanchard, R.W., \& Biller, H.B. (1971). Father availability and academic performance among third grade boys. Developmental Psychology, 4 , 301-305.

Block J. (1971). Lives through-time. Berkeley, Ca.: Bancroft Books.

Block, J.; von der Lipp, A.; \& Block, J.H. (1973). Sex role and socialization: Some personality concomitants and environmental antecedents. Journal of Consulting and Clinical Psychology, 41, 321-341.

Brofenbrenner, U. (1961). Some familial antecedents of responsibility and leadership in adolescents. In L. Petrullo \& B.M. Bass (Eds.), Leadership and interpersonal behavior. New York: Holt, Rinehart, and Winston, pp. 239-272.

Brunkan, R.J., \& Crites, J.0. (1964). An inventory to measure the parental attitude variables in Roe's theory of vocational choice. Journal of Counseling Psychology, 11, 3-12.

Cattell, R.B. (1965). The scientific analysis of personality. Baltimore: Penguin.

Comrey, R.B., (1970). Comrey Personality Scales. San Diego, Ca.: Educational and Industrial Testing Service.

Comrey, R.B., \& Backer, T.E. (1970). Construct validation of the Comrey Personality Scales. Multivariate Behavioral Research, 5 , 469-477.

Coopersmith, S. (1967). The antecedents of self-esteem. San Francisco: W.H. Freeman.

Crandall, et al. (1964). Parents' attitudes and behaviors and gradeschool children's academic achievements. Journal of Genetic Psychology, 104, 53-66.

Distler, L.S. (1964). Patterns of parental identification: An examination of three theories. Ph.D. dissertation, University of California, BerkeTey. 
Epstein, A. \& Radin, N. (1976). Motivational components related to father behavior and cognitive functioning in preschoolers, Child Development, $\underline{46}, 831-389$.

Eysenck, H.J. \& Eysenck, S.B.G. (1969). Personality structure and measurement. San Diego: Knapp.

Fish, K.D. \& Biller, H.B. (1973). Perceived childhood paternal relationships and college females' personal adjustment, Adolescence, $\underline{8}$, 415-420.

Goodenough, E.W. (1957). Interest in persons as an aspect of sex differences in the early years. Genetic Psychology Monographs, 55, 287-323.

Guilford, J.P. (1959), Personality. New York: McGraw-Hill.

Hansen, M.D. (1988). Paternal acceptance and nurturance received a fathers' acceptance and nurturance of their sons, Unpublished Master's Thesis, University of Rhode Island, Kingston, Rhode Island.

Heilbrun, A.B., Jr. (1965). An empirical test of the modeling theory of sex-role learning. Child Development, 36, 789-799.

Heilbrun, A.B., Jr. (1974). Parent identification and filial sex-role behavior: The importance of biological context. In J.C. Cole \& R. Dienstbier (Eds.), Nebraska Symposium on Motivation, 1973. Lincoln: University of Nebraska Press, pp. 125-194.

Hetherington, E.M.; Cox, M.; \& Cox, R. (1978). The aftermath of divorce. In J.H. Stevens \& M. Mathews (Eds.), Motherchild fatherchild relationships. Washington, D.C.; National Association for the Education of Young Children.

Hetherington, E.M.; Cox, M.; \& Cox, R. (1982). Effects of divorce on parents and children. In M.E. Lamb (Ed.) Nontraditional families, Hillsdale, New Jersey: Lawrence Erlbaum Associates.

Honzik, M.P. (1967). Environmental correlates of mental growth: Prediction from the family setting at 21 months. Child Development, $38,388-364$. 
Huck le, L.H. (1984). Personality correlates of parental maltreatment. Dissertation Abstracts International, 44, 3592-B.

Johnson, M.M. (1963). Sex-role learning in the nuclear family. Child Development, 34, 319-333.

Joreskog, K.G., \& Sorbom, D. (1984). LISREL VI. Mooresville, IN.: Scientific Software.

Lamb, M.E. (Ed.). (1976). The role of the father in child development. New York: Wiley.

Lamb, M.E. (1977). The development of parental preferences in the first two years of life. Sex Roles, $\underline{3}, 495-497$.

Lamb, M.E. (1978). Qualitative aspects of mother-infant and fathe infant attachments. Infant Behavior and Development, 1, 265-275.

Lamb, M.E. (1979). Paternal influence and the father's role: A personal perspective. American Psychologist, 34, 938-943.

Lynn, D.B. (1974). The father: His role in child development. Belmont, Calif.: Brooks/Cole.

Lynn, D.B. (1979). Daughters and parents: Past, present, and future. Belmont, calif.: Brooks/Cole.

Medinnus, G.N. (1965). Adolescents' self acceptance and perceptions of their parents. Journal of Consulting Psychology, 29, 150-154.

Mussen, P.H. (1961). Some antecedents and consequences of masculine sex-typing in adolescent boys. Psychological Monographs, 75, No. 2 (Whole No. 505).

Mussen, P.H. \& Distler, L. (1959). Masculinity, identification, and father-son relationships. Journal of Abnormal and Social Psychology, 59, 350-356. 
Mussen, P.H. \& Rutherford, E.E. (1963). Parent-child relationships and parental personality in relation to young children's sex role preferences. Child Development, 34, 589-607.

Nakamura, C.V., \& Rogers, M.M. (1969). Prents' expectations of autonomous behavior and children's autonomy. Developmental Psychology, 1 , 613-617.

Parke, R.D. (1979). Perspectives on father-infant interaction. In J.D. Osofsky (Ed.), The handbook of infant development. New York: Wiley, pp. 549-590.

Parsons, T. (1955). Family Structure and the Socialization of the child. In T. Parsons \& R.F. Bales (Eds.), Family, socialization and interaction process. Glencoe, I1l.: Free Press, pp. 25-131.

Payne, D.E. \& Mussen, P.H. (1956). Parent-child relations and father identification among adolescent boys. Journal of Abnormal and Social Psychology, 52, 358-362.

Plank, E.H. \& Plank, R. (1954). Emotional components in arithmetic learning as seen through autobiographies. Psychoanalytic Study of the Child, $\underline{9}, 274-293$.

Radin, N. (1972). Father-child interaction and the intellectual functioning of four-year-old boys. Developmental Psychology, $\underline{6}, 353-361$.

Radin N. (1974). Observed maternal behavior with four-year-old boys and girls in lower class families. Child Development, 45, 1126-1131.

Radin, N. (1976). The role of the father in cognitive, academic, and intellectual development. In M.E. Lamb (Ed.), The role of the father in child development. New York: Wiley, pp. 237-267.

Radin, N. (1981). The role of the father in cognitive, academic, and intellectual development. In M.E. Lamb (Ed.), The role of the father in child development. (2nd Ed.). New York: Wiley, $\overline{p p}, \overline{379}-\overline{42} 7$. 
Reuter, M.W., \& Biller, H.B. (1973). Perceived paternal nurturanceavailability and personality adjustment among college males. Journal of Consulting and Clinical Psychology, 40, 339-342.

Rosenberg, M. (1965). Society and the adolescent self-image.

Princeton, New Jersey: Princeton University Press.

Rothbart, M.K., \& Maccoby, E.E. (1966). Parents' differential reactions to sons and daughters. Journal of Personality and Social Psychology, 4 , 237-243.

Sears, P.S. (1953). Child-rearing factors related to playing of sextyped roles. American Psychologist, 8, 431.

Sears, R.R. (1970). Relations of early socialization experiences to self-concepts and gender role in middle childhood. Child Development, 41, 267-289.

Sears, R.R.; Rau, L.; \& Alpert, R. (1965). Identification and child rearing. Stanford, Calif.: Stanford University Press.

Shaw, M.C. \& White, D.L. (1965). The relationship between child-parent identification and academic underachievement. Journal of Clinical Psychology, 21, 10-13.

Shinn, M. (1978). Father absence and children's cognitive development. Psychological Bulletin, 85, 295-324.

Torgoff, I. \& Dreyer, A.S. (1961). Achievement inducing and independence granting synergistic parental role components: Relation to daughter's parental role orientation and level of aspiration. American Psychologist, 16, 345 (Abstract).

Velicer, W.F. (1976). Determining the number of components from the matrix of partial correlations. Psychometrika, 41, 321-327.

Willemsen, E.; Flaherty, D.; Heaton, C.; \& Ritchey, G. (1974). Attachment behavior of one-year-olds as a function of mother vs. father, sex of child, session, and toys. Genetic Psychology Monographs, 90, 305-324. 
Zwick, W.R. \& Velicer, W.F. (1982). Factors influencing four rules for determining the number of components to retain. Multivariate Behavioral Research, 17, 253-269. 
TABLE 1

FRI FATHER NURTURANCE ITEMS

Item

Number Item

21. My father didn't care about what kind of grades I got in school. (R)

32. My father was not concerned about the company I kept. (R)

39. I could rely upon my father if it was necessary.

40. If I got into serious trouble my father would do what he could to help.

48. My father seldom encouraged me in anything. ( $R$ )

51. When I got into serious trouble I could expect very little help from my father in getting things straightened out. ( $R$ )

57. My father never seemed interested in the things I did at school. (R)

59. When my father promised me something, I knew that he would keep the promise.

67. I felt as if my father was concerned about how I was growing up.

82. My father didn't care about when I got home from school or dates. (R) 
TABLE 2

\section{FRI FATHER ACCEPTANCE ITEMS}

I tem

Number

4. My father seldom asked my opinion on anything. (R)

10. If I asked my father about sex matters, he would explain them in a manner that I understood.

16. It was hard for me to talk about my personal thoughts and problems to my father. (R)

36. I could tell my father about things that happened on a date without being afraid of prying questions being asked.

37. My father tried to look at my companions through my eyes.

42. My father would often abide by my will even though he did not agree.

43. There were many times when I wished that my father better understood how I felt about things. (R)

46. I hardly ever took any of my personal problems to my father. (R)

58. Quite often I'd get a quick, emphatic "No" from my father even though my request was reasonable. (R)

65. My father asked for my opinion and considered it seriously. 
TABLE 3

FRI MOTHER NURTURANCE ITEMS

I tem

Number

15. My mother never seemed to be very concerned about what I did or where I had been ( $R$ )

17. I spent more time with a nurse or baby sitter during childhood than I did with my mother. (R)

19. I can remember going hungry because no one prepared my meals. (R)

24. My mother showed little concern over my illnesses. (R)

29. I seldom received gifts from my mother - even on special occasions. (R)

56. My mother seldom "tucked" me into bed. (R)

64. I hardly ever sat on my mother's lap when I was young. (R)

66. My mother showed little concern if I "wandered off" for as long as half a day ' $R$ )

71. My mother never seemed interested in the things I made for her in school. (R)

75. I felt that my mother could have kept my clothes nicer. (R) 
TABLE 4

FRI MOTHER ACCEPTANCE ITEMS

I tem

Number

9. Item
that my mother criticized me unjustly.

13. I could tell my mother about my dates without fearing that she would ask prying questions.

14. I seldom talked over my personal problems with my mother. (R)

27. I felt that my mother understood me.

34. My mother asked for my opinion and considered it seriously.

35. My mother asks rather than tells me to do things.

47. My mother would take time out to play with me if I wanted her to.

68. My mother treated me pretty much as her equal.

74. I can remember my mother encouraging me to make "small" decisions when I was quite young.

81. My mother tried to look at my companions through my eyes. 
TABLE 5

SCALE SCORES FOR EIGHT FRI SCALES FOR FATHERS (F), MOTHERS (M), AND CHILDREN (C) ON THE NURTURANCE (NUR) AND ACCEPTANCE (ACC) SCALES

\begin{tabular}{lccc} 
Scale & Mean & SD & Coefficient Alpha \\
\hline FNUR-C & 5.08 & .67 & .77 \\
FACC-C & 3.57 & .85 & .82 \\
MNUR-C & 5.28 & .60 & .75 \\
MACC-C & 4.15 & .82 & .83 \\
FNUR-F & 4.63 & .88 & .72 \\
FACC-F & 3.16 & .93 & .86 \\
FNUR-M & 4.68 & .94 & .79 \\
FACC-M & 3.05 & .98 & .87 \\
\hline
\end{tabular}

Note. No. of items $=10$ per scale.

$N=250$. 
TABLE 6

PEARSON PRODUCT-MOMENT CORRELATION COEFFICIENTS FOR FATHERS (F) AND CHILDREN (C): NURTURANCE (NUR) AND ACCEPTANCE (ACC) SCALES

FNUR-C

1.00

FACC-C

$.32 \star$

.16

.13

1.00

FACC - F

$-.06$

FNUR-F

FACC - F

FACC $-C$

1.00

FNUR-F

6

.13

.11

$.42^{\star}$

1.00

Note. All correlations based on $N=250$.

$\star_{p}<.001$ 
TABLE 7

PEARSON PRODUCT-MOMENT CORRELATION COEFFICENTS FOR MOTHERS (M) AND CHILDREN (C): NURTURANCE (NUR) AND ACCEPTANCE (ACC) SCALES

MNUR-C

$$
1.00
$$

MACC $-C$

$.40 \star$

1.00

FNUR-M

.02

.03

.04

$-.06$

FACC $-M$
MACC-C

FNUR-M

FACC $-M$

MNUR-C $\quad 1.00$$$
\text { . }
$$

Note. Al1 correlations based on $N=250$.

$\star_{p}<.001$. 
TABLE 8

SCALE SCORES FOR EIGHT CPS SCALES

\begin{tabular}{lccc} 
Scale & MEAN & SD & Coefficient Alpha \\
\hline TSCALE & 4.18 & .53 & .76 \\
SSCALE & 4.83 & .80 & .90 \\
MSCALE & 3.67 & .91 & .87 \\
PSCALE & 4.91 & .75 & .89 \\
OSCALE & 4.39 & .67 & .83 \\
CSCALE & 4.39 & .53 & .78 \\
ASCALE & 4.79 & .70 & .87 \\
ESCALE & 4.37 & .92 & .92
\end{tabular}

Note. No. of items $=20$ per scale.

$$
N=250 \text {. }
$$


TABLE 9

PEARSON PRODUCT-MOMENT CORRELATION COEFFICIENTS (CPS)

\begin{tabular}{|c|c|c|c|c|c|c|c|c|}
\hline & $\mathrm{T}-\mathrm{Sc}$ & $S-S c$ & $M-S c$ & $P-S C$ & $0-5 c$ & $C-S c$ & $\mathrm{~A}-\mathrm{SC}$ & $\mathrm{E}-\mathrm{SC}$ \\
\hline T-SC & 1.00 & & & & & & & \\
\hline$S-S C$ & $.32^{\star}$ & 1.00 & & & & & & \\
\hline$M-S C$ & -.10 & .17 & 1.00 & & & & & \\
\hline $\mathrm{P}-\mathrm{SC}$ & $.31 \star$ & .13 & $-.36 *$ & 1.00 & & & & \\
\hline $0-S c$ & -.06 & .06 & -.14 & .17 & 1.00 & & & \\
\hline $\mathrm{C}-\mathrm{Sc}$ & .13 & .18 & -.12 & .06 & $.26^{\star}$ & 1.00 & & \\
\hline$A-S C$ & .09 & $.34 *$ & .15 & $.25 *$ & $.37^{\star}$ & .16 & 1.00 & \\
\hline$E-S C$ & .17 & $.42^{\star}$ & -.01 & $.26 *$ & -.01 & .01 & $.34^{\star}$ & 1.00 \\
\hline
\end{tabular}

Note. All correlations based on $N=250$.

$$
{ }^{*} \mathrm{p}<.001
$$


TABLE 10

SCALE SCORES FOR SIXTEEN SUBSCALES (FRI)

\begin{tabular}{llcc} 
Scale & Mean & SD & Coefficient Alpha \\
\hline FNUR-C (A) & 5.12 & .73 & .78 \\
FNUR-C (B) & 5.03 & .72 & .76 \\
FACC-C (A) & 3.60 & .90 & .77 \\
FACC-C (B) & 3.54 & .96 & .72 \\
MNUR-C (A) & 5.34 & .64 & .75 \\
MNUR-C (B) & 5.21 & .68 & .78 \\
MACC-C (A) & 4.19 & .82 & .73 \\
MACC-C (B) & 4.11 & .80 & .74 \\
FNUR-F (A) & 4.54 & .99 & .77 \\
FNUR-F (B) & 4.72 & .86 & .73 \\
FACC-F (A) & 3.24 & .96 & .75 \\
FACC-F (B) & 3.07 & .99 & .75 \\
FNUR-M (A) & 4.60 & .98 & .86 \\
FNUR-M (B) & 4.76 & .99 & .81 \\
FACC-M (A) & 3.22 & .97 & .77 \\
FACC-M (B) & 2.88 & .95 & .75 \\
\hline
\end{tabular}

Note. No. of items $=5$ per scale. $N=250$.

(A) and (B) refer to the split (5-item) subscales for each of the original (10-item) FRI scales. 
TABLE 11

MEANS, STANDARD DEVIATIONS, F RATIOS, AND EFFECT SIZE FOR FOLLOW-UP ANOVAS FOR CPS SCALES: HIGH VS. LOW FATHER NURTURANCE

FATHER NURTURANCE

$$
\text { Low }(n=121) \quad \text { High }(n=129)
$$

\begin{tabular}{lcccccc} 
Scale & Mean & SD & Mean & SD & $F(1,246)$ & et $^{2}$ \\
\hline TSCALE & 4.13 & .50 & 4.23 & .52 & 1.95 & -- \\
SSCALE & 4.67 & .75 & 4.97 & .78 & $9.02 \star \star$ & .035 \\
PSCALE & 4.83 & .70 & 4.96 & .72 & 2.92 & -- \\
MSCALE & 4.16 & .71 & 4.31 & .72 & 3.78 & -- \\
OSCALE & 4.31 & .61 & 4.39 & .62 & 1.74 & -- \\
CSCALE & 4.23 & .52 & 4.58 & .54 & $10.95 \star \star$ & .043 \\
ASCALE & 4.73 & .70 & 4.85 & .73 & 2.42 & -- \\
ESCALE & 4.23 & .85 & 4.49 & .86 & $5.02 \star$ & .020 \\
\hline
\end{tabular}

$\begin{aligned} \star p & <.05 \\ \star \star p & <.01\end{aligned}$ 
TABLE 12

MEANS, STANDARD DEVIATIONS, F RATIOS, AND EFFECT SIZE FOR FOLLOW-UP ANOVAS FOR CPS SCALES: MALES VS. FEMALES

Males $(n=126) \quad$ Females $(n=124)$

\begin{tabular}{lcccccc} 
Scale & Mean & SD & Mean & SD & $F(1,246)$ & eta $^{2}$ \\
\hline TSCALE & 4.10 & .51 & 4.26 & .54 & $6.33^{\star \star}$ & .025 \\
SSCALE & 4.84 & .78 & 4.81 & .83 & 0.07 & - \\
PSCALE & 4.60 & .72 & 5.22 & .65 & $48.83^{\star \star}$ & .166 \\
MSCALE & 4.23 & .73 & 3.11 & .71 & $151.38 \star \star$ & .382 \\
OSCALE & 4.35 & .61 & 4.43 & .72 & 1.04 & -- \\
CSCALE & 4.38 & .53 & 4.41 & .54 & 0.06 & -- \\
ASCALE & 4.87 & .70 & 4.70 & .70 & $3.97 \star$ & .016 \\
ESCALE & 4.30 & .86 & 4.43 & .87 & 1.13 & -- \\
\hline
\end{tabular}

$\begin{aligned} \star_{p} & <.05 \\ \star * p & <.001\end{aligned}$ 


\section{FIGURE 1}

STRUCTURAL EQUATION MODEL:

NURTURANCE AND ACCEPTANCE FOR FATHERS AND CHILDREN

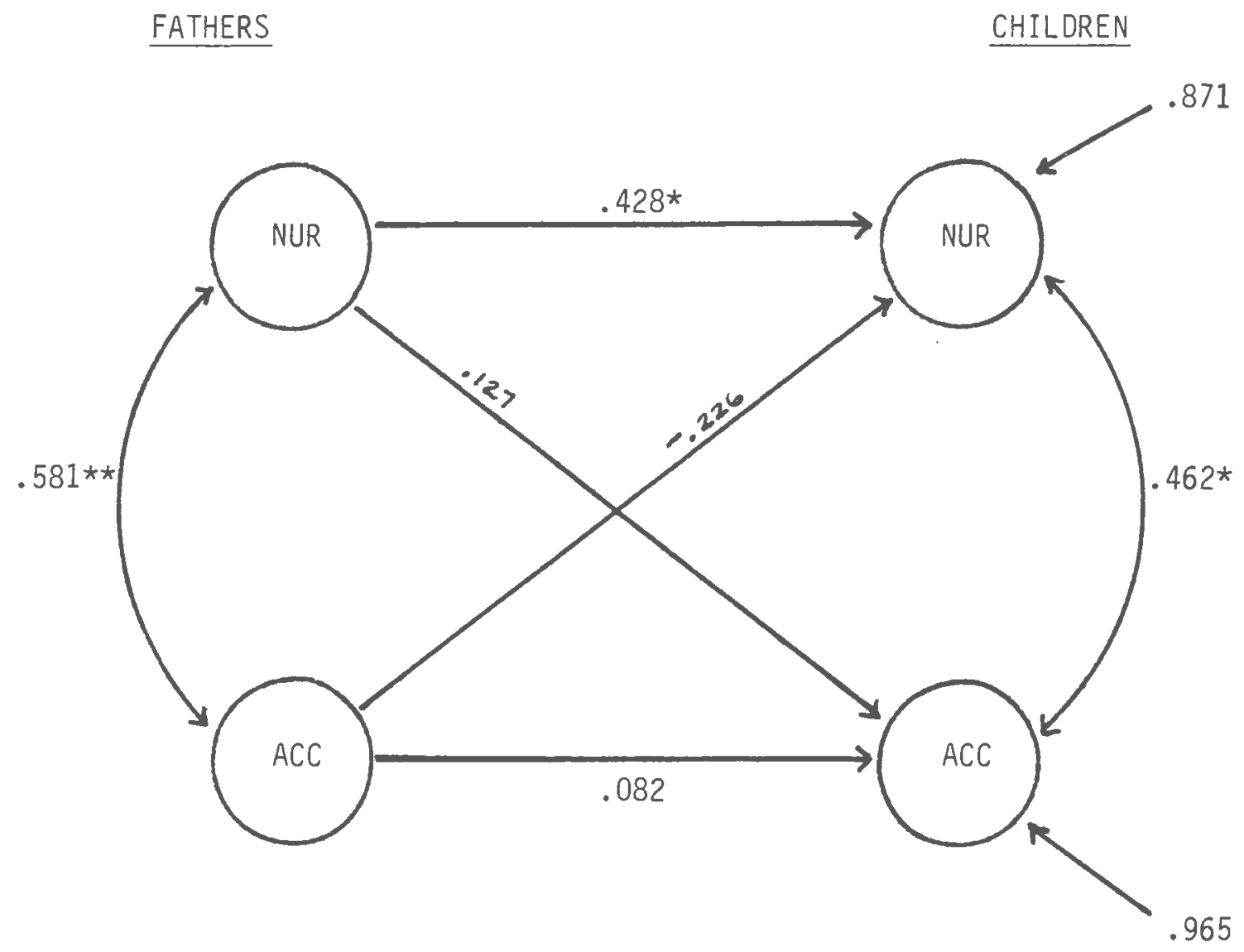

Note. All path parameter estimates based on $N=250$.

$\star_{p}<.05$

$\star \star p<.01$ 


\section{FIGURE 2}

STRUCTURAL EQUATION MODEL:

NURTURANCE AND ACCEPTANCE FOR FATHERS AND SONS

\section{FATHERS}

$\underline{\text { SONS }}$

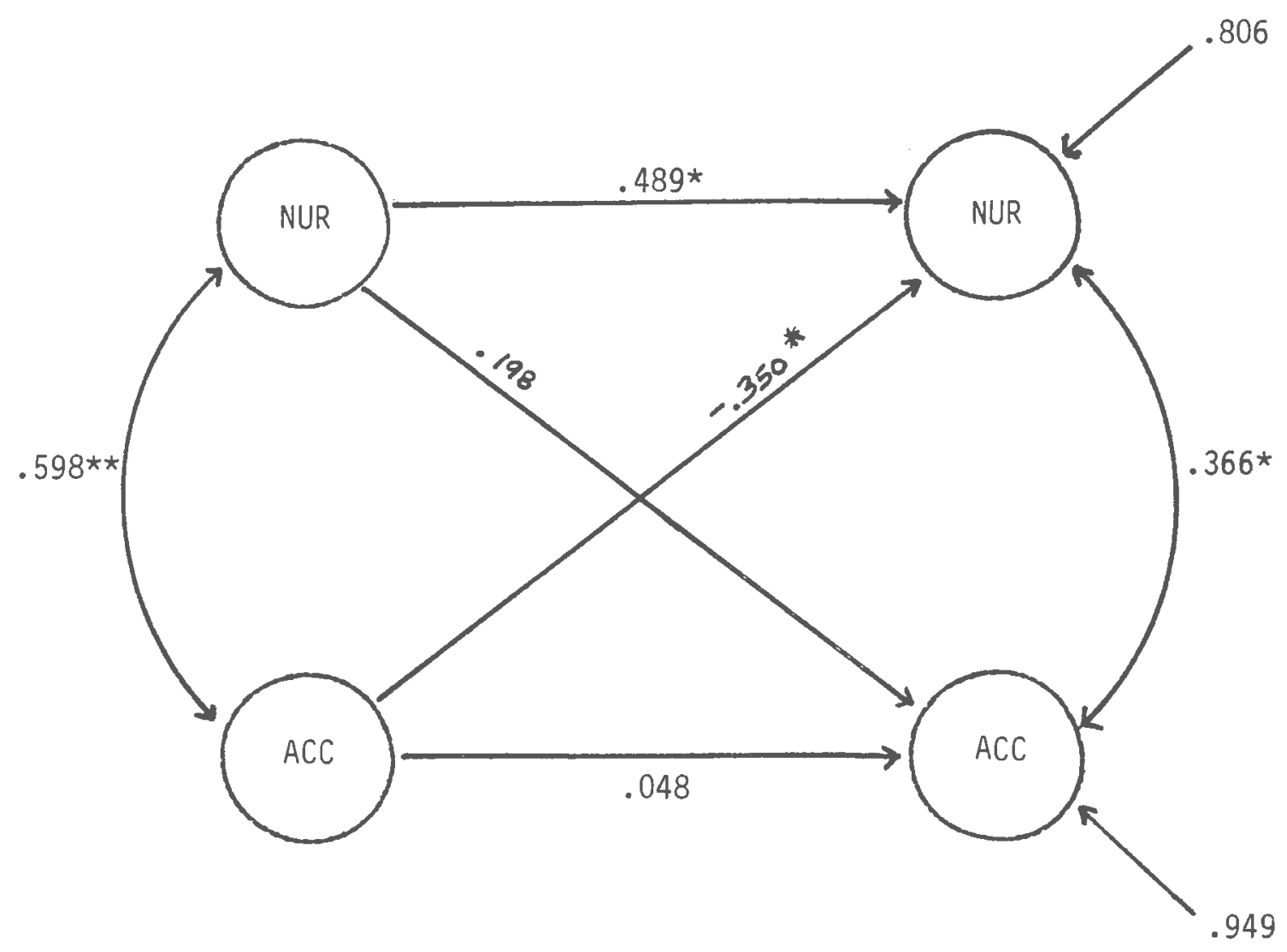

Note. All path parameter estimates based on $N=250$.

$\star_{p}<.05$

$\star \star p<.01$ 


\section{FIGURE 3}

STRUCTURAL EQUATION MODEL:

NURTURANCE AND ACCEPTANCE FOR FATHERS AND DAUGHTERS

\section{FATHERS}

DAUGHTERS

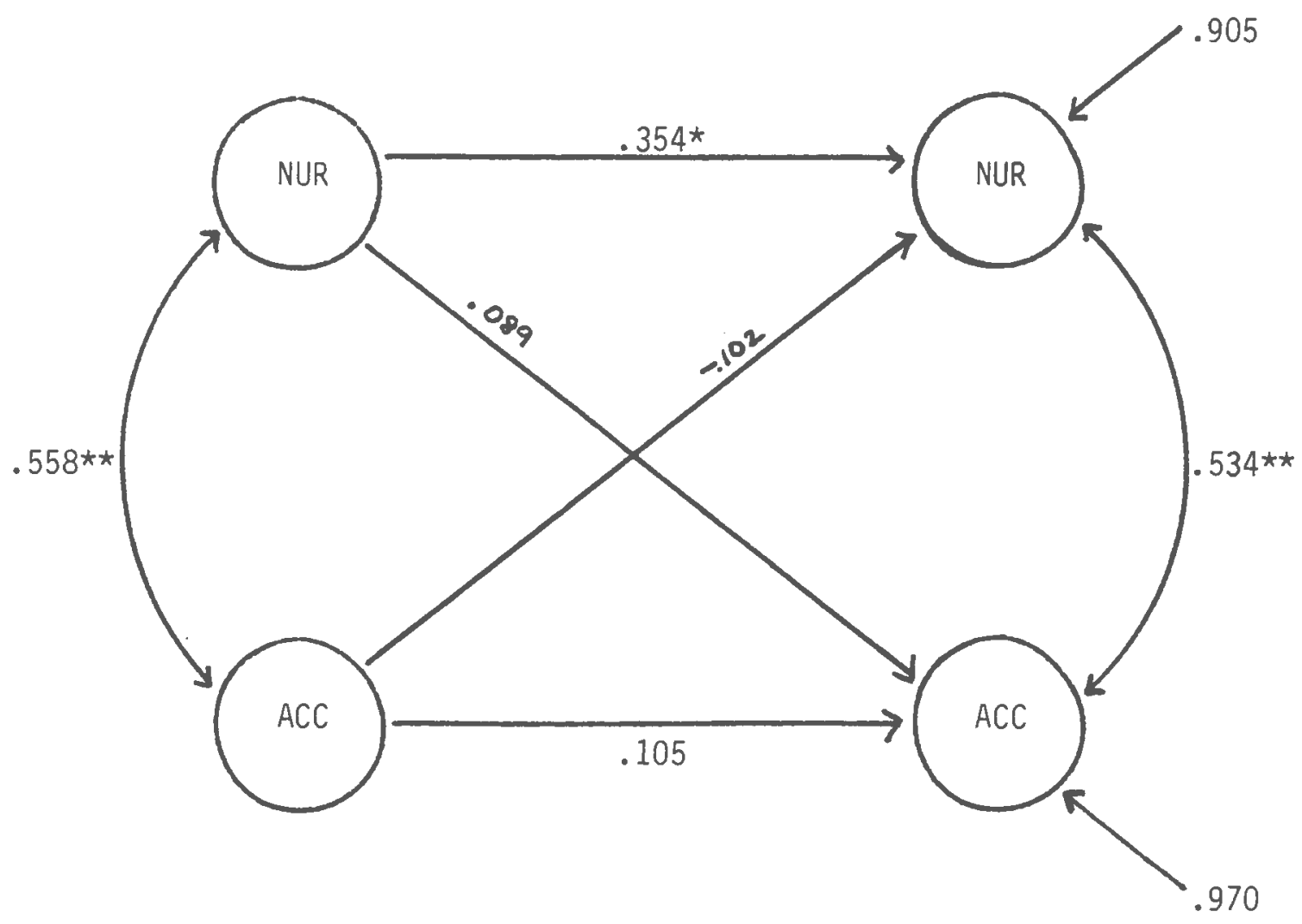

Note. All path parameter estimates based on $N=250$.

$\star_{p}<.05$

$\star \star p p<.01$ 


\section{FIGURE 4}

STRUCTURAL EQUATION MODEL:

NURTURANCE AND ACCEPTANCE FOR MOTHERS AND CHILDREN

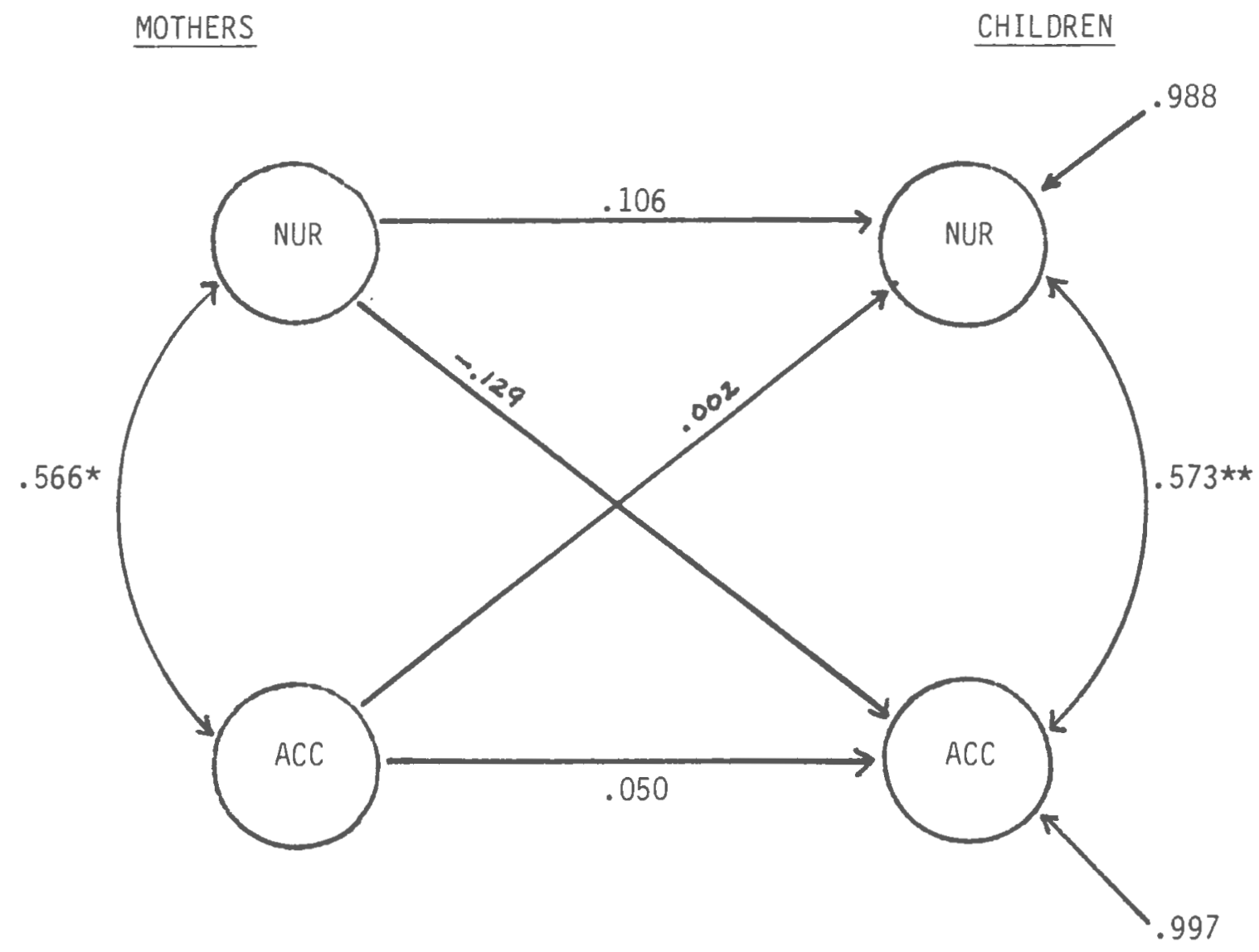

Note. All path parameter estimates based on $N=250$.

$\star_{p}<.01$ 


\section{FIGURE 5}

STRUCTURAL EQUATION MODEL:

NURTURANCE AND ACCEPTANCE FOR MOTHERS AND SONS

MOTHERS

SONS

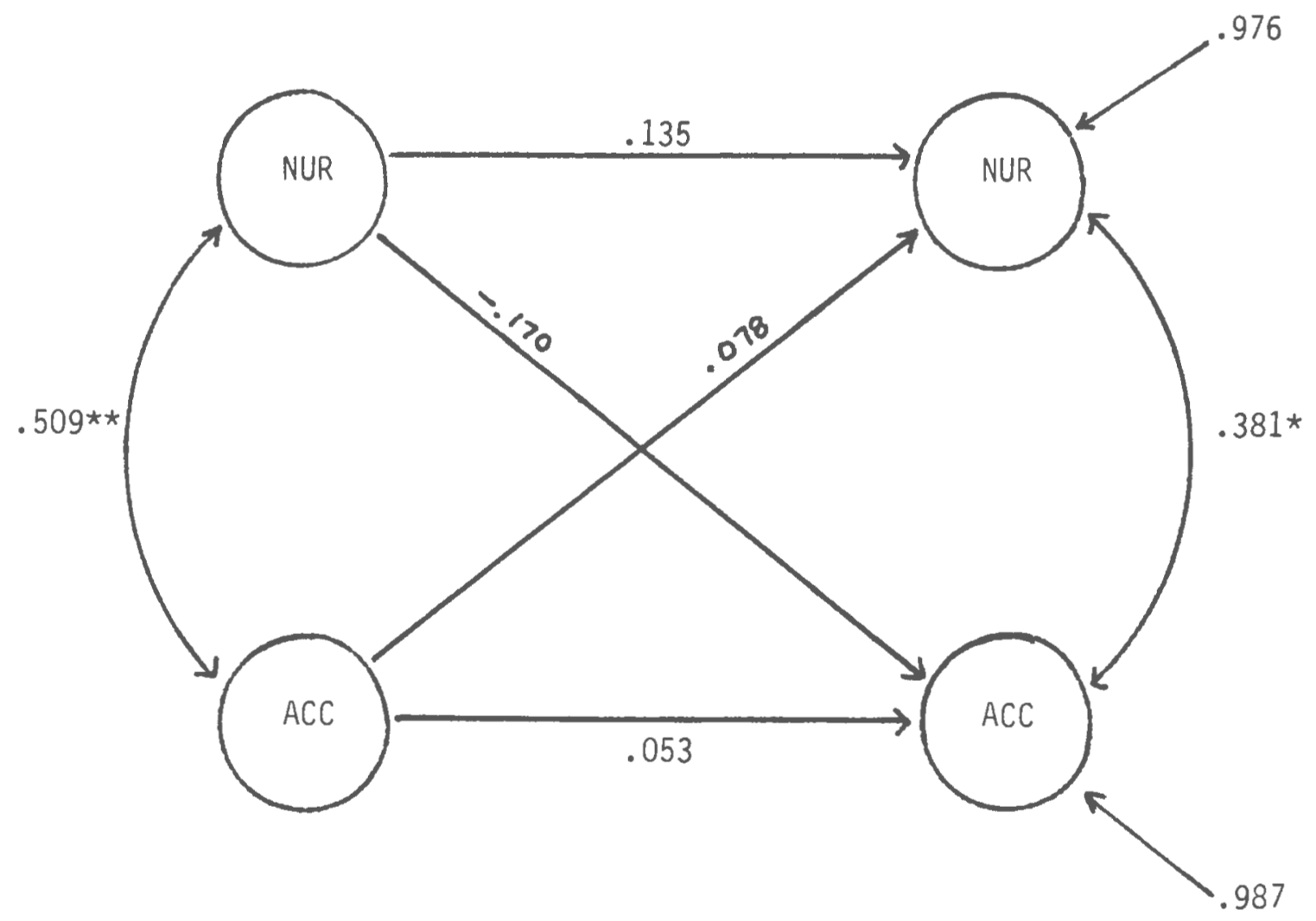

Note. All path parameter estimates based on $N=250$.

$\star_{p}<.05$

$\star \star p<.01$ 


\section{FIGURE 6}

STRUCTURAL EQUATION MODEL:

NURTURANCE AND ACCEPTANCE FOR MOTHERS ÄND DAUGHTERS

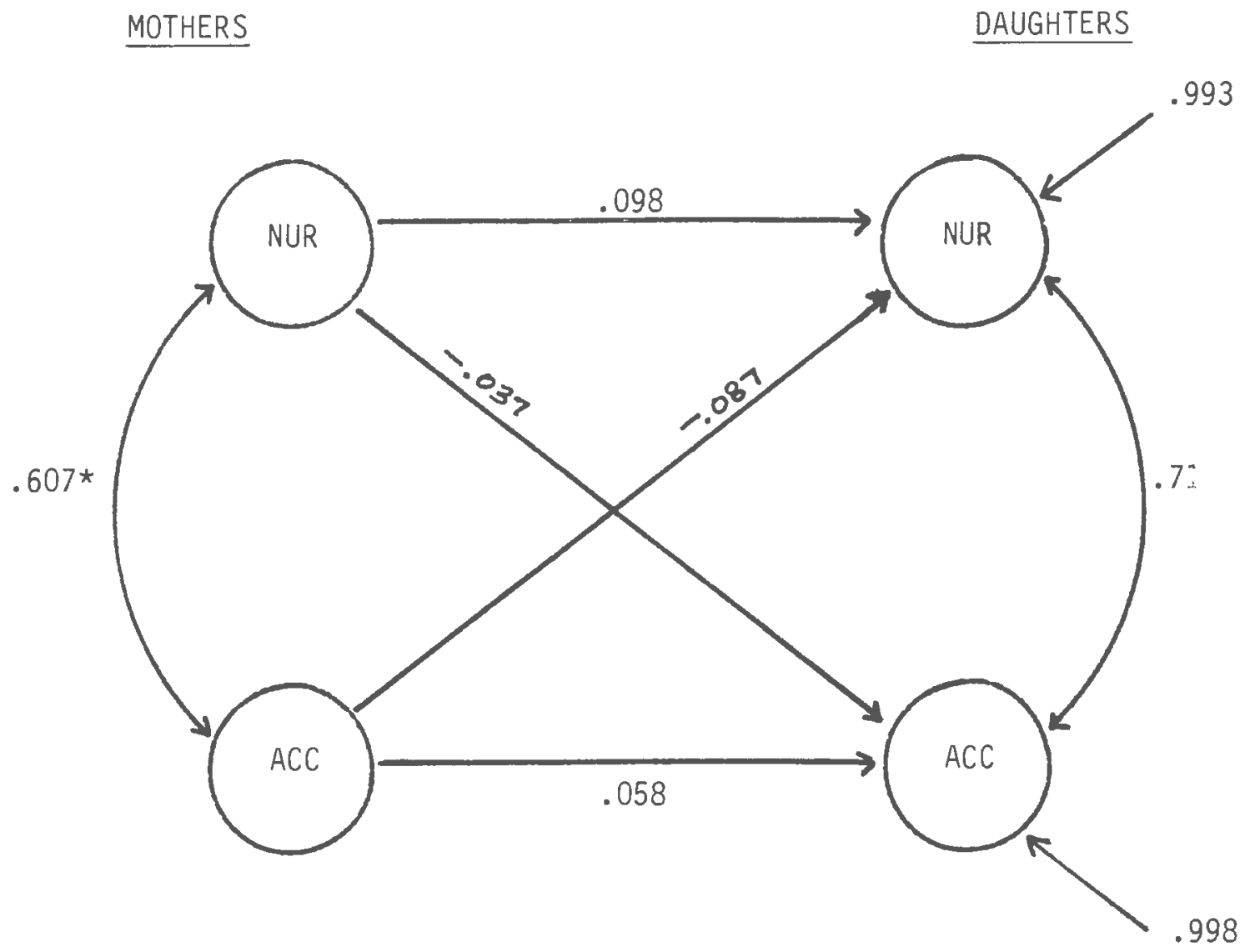

Note. All path parameter estimates based on $N=250$.

$\star_{p}<.001$ 
APPENDIX 


\section{PARTICIPANT'S CONSENT FORM}

This research project is expected to add to our knowledge of the fathering role. Aside from students receiving research participation credits, we cannot and do not guarantee that participants will derive any direct benefit from the present project. There are no risks inherent in the research project.

Participation in the study is purely voluntary and can be withdrawn at any time. Participants will be asked to complete three questionnaires which inquire about basic demographic and family information. Participation will take no longer than 90 minutes to complete the questionnaires.

Participants must be 18 years of age or older. Information about participants gathered at any stage in this project will be kept strictly confidential. Record forms will be anonymous and participants will not be personally identified in any published or unpublished reporting of the results.

Participants will have the opportunity to receive a brief summary of th findings at the conclusion of the research project. If participants have any questions they may contact Michael Hansen, Department of Psychology, University of Rhode Island at (401) 792-4224.

STATEMENT OF INFORMED CONSENT

I ACKNOWLEDGE THAT I HAVE READ AND FULLY UNDERSTAND THE ABOVE CONSENT AND I AGREE TO PARTICIPATE IN THIS PROJECT. 


\section{FAMILY DATA QUESTIONNAIRE}

\section{PART I}

Please begin by answering the first set of questions which ask for specific information about your personal and family history. Answer the questions by either filling in the blanks with the information requested (e.g., your age) or by circling the number corresponding to the multiplechoice answer which best applies to you (e.g., marital status). Be sure to answer all questions as accurately as you can.

1. What is your current age?

2. What is your sex?

3. What is your marital status?

$$
\begin{array}{ll}
1=\text { Single } & 4=\text { Widowed } \\
2=\text { Married } & 5=\text { Living with someone as if married } \\
3=\text { Separated/divorced } &
\end{array}
$$

4. Do you have any children? If yes, how many?

5. How many brothers and/or sisters do you have?

6. How many step/half brothers and/or sisters do you have?

7. What is your position in your family?

$$
\begin{array}{ll}
1=\text { Only child } & 3=\text { Middle child of three or more } \\
2=\text { 0ldest child } & 4=\text { Youngest child }
\end{array}
$$

8. What is your predominant racial background?

$$
\begin{array}{ll}
1=\text { Black } & 3=\text { Native American } \\
2 \text { = Caucasian/White } & 4=\text { Oriental }
\end{array}
$$

9. What is your predominant ethnic background?

$$
\begin{array}{lll}
1 \text { British Isles } & 4=\text { Italian } & 7=\text { Scandanavian } \\
\text { (specify) } & 5=\text { German } & 8=\text { Latin American } \\
2=\text { French } & 6=\text { Slavic } & 9=\text { Other } \\
3=\text { Portugese } &
\end{array}
$$


FAMILY DATA QUESTIONNAIRE (continued)

10. What is your predominant religious background?

$$
\begin{array}{ll}
1=\text { Roman Catholic } & 3 \text { = Jewish } \quad 5=\text { Other } \\
2 \text { = Protestant } & 4=\text { No religion }
\end{array}
$$

The questions which follow pertain to specific information about your mother and your father. If you did not have a mother or a father, answer regarding the person who acted most like a father or mother and indicate his or her relationship to you.

11. I am answering regarding:

$$
1 \text { = Mother } \quad 2 \text { = Stepmother } \quad 3=\text { Other }
$$

12. I am answering regarding:

$$
1=\text { Father } \quad 2 \text { = Stepfather } \quad 3=\text { Other }
$$

13. What is your mother's age?

14. Indicate which of the following categories best describes your mother's occupation:

$1=$ Unskilled or semi-skilled worker (e.g., factory work)

2 = Skilled worker or foreman (e.g., machinist, cook)

$3=$ Farmer

4 = Clerical or salesperson (but not manager)

5 = Proprietor (i.e., owner of a business)

6 = Professional (e.g., architect, teacher, nurse) or managerial position (e.g., department head, store or office manager)

7 = No occupation outside home

15. Indicate the highest level of education attained by your mother:

1 = Some elementary school

2 = Completed elementary school

3 = Some high school

4 = Completed high school 
FAMILY DATA QUESTIONNAIRE (continued)

5 = Professional, business, or technical training in addition to high school

6 = Some college

7 = Complete college (i.e., 4 years)

8 = Professional, business, or technical training in addition to college

9 = Some graduate work

$10=$ Completed graduate degree (e.g., M.A., Ph.D., M.D.)

16. What is your father's age?

17. Indicate which of the following categories best describes your father's occupation:

1 = Unskilled or semi-skilled worker (e.g., factory work)

2 = Skilled worker or foreman (e.g., machinist, cook)

$3=F$ armer

$4=$ Clerical or salesperson (but not manager)

5 = Proprietor (i.e., owner of a business)

6 = Professional (e.g., architect, teacher, nurse) or managerial position (e.g., department head, store or office manager)

7 = No occupation outside home

13. Indicate the highest level of education attained by your father:

1 = Some elementary school

2 = Completed elementary school

3 = Some high school

4 = Completed high school

5 = Professional, business, or technical training in addition to high school 
FAMILY DATA QUESTIONNAIRE (continued)

6 = Some college

7 = Complete college (e.g., 4 years)

8 = Professional, business, or technical training in addition to college

9 = Some graduate work

$10=$ Completed graduate degree (e.g., M.A., Ph.D., M.D.)

19. Please indicate which of the following comes closest to your family' total annual income before taxes:

$1=\$ 7,500$ or less

$2=\$ 7,501$ to $\$ 15,000$

$3=\$ 15,001$ to $\$ 25,000$

$4=\$ 25,001$ to $\$ 35,000$
$5=\$ 35,001$ to $\$ 50,000$

$6=\$ 50,001$ or over

$7=$ Don't know

20. Are your natural parents living together?
$1=$ Yes ( skip to question \#30)
$4=$ No, due to the death of my
$2=$ No, due to a marital separation
$3=$ No, due to a divorce parent ( $s$ ) (skip to ques.\#26)
$5=$ Other (specify)

21. If your parents are separated or divorced, how old were you when they began living apart?

22. With whom did you live after your parents' separation and/or divorce?

$1=$ Mother on ly

$2=$ Mother primarily

$3=$ Mother and father equally
$4=$ Father on $1 y$

$5=$ Father primarily

$6=0$ ther (specify)

23. If you lived primarily with one parent, how often did you visit or see your other parent?

$1=$ Not at al

2 = Occasionally, unpredictably

$3=$ Frequent $7 y$, unpredictably

$4=1-2$ times a year, predictabiy

$5=3-6$ times a year, predictably

$\sigma=$ About monthly, predictably
7 = About every two weeks, predictably

8 = About weekly, predictably

$9=$ More often than week ly, predictably

$10=$ other $($ specify $)$ 


\section{FAMILY DATA QUESTIONNAIRE (continued)}

24. How did your parent's separation and/or divorce affect your relationship with your mother?
$1=$ Became much closer
2 = Became a little bit closer
4 = Became somewhat distant
$3=$ No real change
$5=$ Became very distant
6 = Other (specify)

25. How did your parent's separation and/or divorce affect your relationship with your father?
$1=$ Became much closer
$2=$ Became a little bit closer
$3=$ No real change
4 = Became somewhat distant
5 = Became very distant
$6=$ Other (specify)

26. If your parents' marriage ended, did your mother remarry or live with someone as if married? (If yes, please indicate your age at the time.)
$1=$ Yes $($ age
2 = No (skip to \#28)

27. If you have a stepfather (or someone who acts like a stepfather), looking back over your relationship with him how close have you and he been?
$1=$ Very close
$2=$ Close
$3=$ Somewhat close
$5=$ Distant

28. If your parents' marriage ended, did your father remarry or live with someone as if married? (If yes, please indicate your age at the time.)
$1=$ Yes $($ age
$2=$ No (skip to \#30)

29. If you have a stepmother (or someone who acts like a stepmother), looking back over your relationship with her how close have you and she been?
$1=$ Very close
3 = Somewhat close
$5=$ Distant
$2=$ Close
$4=$ Not close

30. Over the course of your childhood, who was primarily responsible for your day-to-day care?

$1=$ Mother

$2=$ Father

$3=$ Mother and father equaliy

4 = Stepmother
$5=$ Stepfather

$6=$ Grandparent

$7=\operatorname{Brother}(\mathrm{s}) /$ sister $(\mathrm{s})$

$8=$ One or two consistent babysitters in your home 


\author{
9 = several different baby sitters \\ in your home \\ $10=$ Consistent daycare home/center \\ 11 = Several different daycare \\ homes/centers \\ $12=0$ ther (specify)
}

\title{
PART II \\ FAMILY RELATIONS INVENTORY
}

The statements which follow concern your relationships with your mother and father from as far back as you can remember. For most people some parts of childhood and adolescence were less satisfactory than they might have been. For this reason, many of the questions ask you to recall what actually happened between you and your parents as you were growing up, compared to how you would have liked your relationship with each of them to have been.

Because everyone tends to forget some parts of their childhood, especially unpleasant experiences, we know that it may be difficult to remember past events accurately. In order to help yourse if remember your past as accurately as possible, please take a few minutes now to think back over your childhood and adolescence. Let your mind focus on particular events and try to create a mental picture of the places you lived, your mother and father, your brothers and sisters and the ways you spent your time. Try to recall some things that interested you, some things you liked and disliked, and some of the feelings you had about yourself and the people around you. In short, try to briefly reconstruct your childhood and adolescence.

Now, read each statement and decide whether it applied to your relationships with your mother or your father. Keep in mind that we are interested in your impressions based on as much as you can remember about your relationships with your mother and your father. (If you did not have a father or a mother, answer regarding the person who acted most like a father or mother and indicate his or her relationship to you.)

Use the following 6-point scale in responding to each statement:

$$
\begin{aligned}
& 1=\text { strongly disagree } \\
& 2=\text { disagree } \\
& 3=\text { disagree somewhat } \\
& 4=\text { agree somewhat } \\
& 5=\text { agree } \\
& 6=\text { strongly agree }
\end{aligned}
$$


FAMILY RELATIONS INVENTORY (continued)

Choose the option that best represents your experience and write the number associated with it in the space provided immediately preceding each statement.

1. I am answering regarding: (circle)

$$
1 \text { = Mother } \quad 2 \text { = Stepmother } \quad 3 \text { = Someone else (specify) }
$$

2. I am answering regarding: (circle)

$$
1 \text { = Father } \quad 2 \text { = Stepfather } \quad 3 \text { = Someone else (specify) }
$$

3. If I got into a quarrel, my father would try to show me who was right and why.

4. My father seldom asked my opinion on anything.

5. My father thinks I should have as much opportunity as possible within reasonable limits.

6. I felt that my father understood me.

7. My mother was willing to listen to my side of the story and give it consideration.

8. My mother never seemed to notice my "pet" projects.

9. I hardly ever felt that my mother criticized me unjustly.

10. If I asked my father about sex matters, he would explain them in a manner that I understood.

11. My mother didn't seem to care about teaching me how to act in social situations.

12. My father had little patience with me when I helped him on an unfamiliar task.

13. I could tell my mother about my dates without fearing that she would ask prying questions.

14. I seldom talked over personal problems with my mother.

15. My mother never seemed to be very concerned about what I did or where I had been.

16. It was hard for me to talk about my personal thoughts and problems to my father. 
FAMILY RELATIONS INVENTORY (continued)

1 = strongly disagree

2 = disagree

3 = disagree somewhat

4 = agree somewhat

5 = agree

6 = strongly agree

17. I spent more time with a nurse or baby sitter during childhood than I did with my mother.

18. As a child I was able to have some secrets without any objections from my mother.

19. I can remember going hungry because no one prepared my meals.

20. At times when I needed him most, my father was usually busy or not around.

21. My father didn't care about what kind of grades I got in school.

22. I often felt that my father wished he could get rid of me.

23. I seldom felt that my father criticized me unjustly.

24. My mother showed little concern over my illnesses.

25. My mother praised more than she blamed but didn't overdo either one.

26. My father seldom gave me gifts - even on special occasions.

27. I felt that my mother understood me.

28. My father was usually interested in what I was doing.

29. I seldom received gifts from my mother - even on special occasions.

30. My father spent very little time with me when I was growing up.

31. My father used to "snap" at me frequently.

32. My father was not concerned about the company I kept.

33. I could "talk back" to my father if I didn't overdo it.

34. My mother asked for my opinion and considered it seriously. 
FAMILY RELATIONS INVENTORY (continued)

1 = strongly disagree

2 = disagree

3 = disagree somewhat

4 = agree somewhat

$5=$ agree

6 = strongly agree

35. My mother asks rather than tells me to do things.

36. I could tell my father about things that happened on a date without being afraid of prying questions being asked.

37. My father tried to look at my companions through my eyes.

38. My mother usually treated others with more consideration and courtesy than she did me.

39. I could rely upon my father if it was necessary.

40. If I got into serious trouble my father would do what he could to help.

41. My mother never bought anything "just for me" (for example, candy) when I went to the store with her.

42. My father would often abide by my will even though he did not agree.

43. There were many times when I wished that my father better understood how I felt about things.

44. I felt like my father was a good friend as well as a parent.

45. My mother always had time to listen if I had a problem to discuss.

46. I hardly ever took any of my personal problems to my father.

47. My mother would take time out to play with me if I wanted her to.

48. My father seldom encouraged me in anything.

49. My mother trusted me.

50. My mother didn't seem interested in explaining things to me. 


\section{FAMILY RELATIONS INVENTORY (continued)}

1 = strongly disagree

2 = disagree

3 = disagree somewhat

$4=$ agree somewhat

$5=$ agree

6 = strongly agree

51. When I got into serious trouble I could expect very little help from my father in getting things straightened out.

52. If I kissed or hugged my mother, she seemed to be embarrassed.

53. My father aTways seemed to be very busy when I asked him for something.

54. My father seldom took the time to explain things to me so that i could understand them.

55. My father had the knack of knowing just when to "put his foot down."

56. My mother seldom "tucked" me into bed.

57. My father never seemed interested in the things I did at school.

58. Quite often I would get a quick, emphatic "NO" from my father even though my request was reasonable.

59. When my father promised me something, I knew that he would keep the promise.

60. My father was a willing listener if I had a problem.

61. My mother seldom gave me much "moral support."

62. I found it next to impossible to have a heart to heart talk with my mother.

63. At times when I needed her most my mother was usually busy or not around.

64. I hardly ever sat on my mother's lap when I was young.

65. My father asked for my opinion and considered it seriousiy.

66. My mother showed little concern if I "wandered off" for as long as half a day. 


\section{FAMILY RELATIONS INVENTORY (continued)}

1 = strongly disagree

$2=$ disagree

3 = disagree somewhat

4 = agree somewhat

5 = agree

6 = strongly agree

67. I felt as if my father was concerned about how I was growing up. 68. My mother treated me pretty much as her equal.

69. My father praised more than he blamed but didn't overdo either one.

70. My mother always seemed to be very busy when I asked her for something.

71. My mother never seemed interested in the things I made for her in school.

72. My mother was often "too busy to listen" to me.

73. My mother knew just how far to let things go before "putting her foot down."

74. I can remember my mother encouraging me to make "small" decisions when I was quite young.

75. I felt that my mother could have kept my clothes nicer.

76. My father seldom showed any interest in my "pet" projects.

77. I enjoyed doing little jobs for my mother.

78. If I got into serious trouble, my mother would do what she could to help me out.

79. My mother would lend a helping hand on a project if I desired it.

80. When I was a child my father gave me about as much "freedom" as my friends' fathers gave them.

81. My mother tried to look at my companions through my eyes.

82. My father didn't care when I got home from school or dates. 


\section{COMREY PERSONALITY SCALES}

(CPS)

Form A

Andrew L. Comrey

The statements in this booklet have been designed to show where you should be placed on several personality traits. There are no "right" or "wrong" answers to these statements. It is impossible, therefore, to get a "good" or a "bad" score on this personality inventory. It is possible only to get scores which will describe your personality either more or less accurately.

DIRECTIONS: For each numbered statement in the booklet, please follow these steps:

1. Read the statement.

2. Note if the statement number is followed by the letter $X$ or $Y$. From the answer sheet, select the answer scale which is designated by the same letter, Scale $X$ or Scale $Y$. All X statements use Scale $X$ and all $Y$ statements use Scale $Y$.

3. Select one answer which is best for you from the seven possible answers in the Scale selected. Note the number to the left of the answer which you select $(7,6,5,4,3,2$, or 1$)$. This is the answer number.

4. Find the place on the SEPARATE ANSWER SHEET which has the same number as the statement you have just read in the booklet.

5. Indicate your answer on the SEPARATE ANSWER SHEET by marking the answer number you have chosen in the correct blank.

For example, since statement 1 on the next page is followed by an $X$, your answer number will be selected from the group of answers named Scale $X$. If after reading the statement and the possible answers in Scale $x$, you decided that the best answer for you was "4. Occasionally," you would indicate this on the SEPARATE ANSWER SHEET as follows:

For Hand Scoring

Answer Sheets:

1.

4

For Machine Scoring $1 \begin{array}{lllllll}1 & 2 & 3 & 4 & 5 & 6 & 7\end{array}$

Answer Sheets:

If some other answer had been selected rather than 4, you would have marked the answer number in the blank instead. If the other answer scale seems more appropriate for you than the one indicated for the given statement, you may use it instead. If you should find it impossible to select an answer that is even approximately correct for you, leave the answer space blank for the statement. Please turn to the next page and begin. 
$1 \mathrm{X}$ The average person is honest.

$2 Y$ I could live in a pig pen without letting it bother me.

3Y This society provides too much protection for criminals.

$4 X$ If I think about exercising, I lie down until the idea goes away.

$5 Y$ If I were asked to lift a ten-ton weight, I could do it.

$6 X$ If feel inferior to the people I know.

$7 X$ I am a very talkative person.

8X Big bugs and other crawling creatures upset me.

9x I am very kindhearted.

10X Other people are selfishly concerned about themselves in what they do.

11X I am a cautious person.

12X If the laws of society are unjust, they should be disobeyed.

13X I love to work long hours.

$14 X$ When I wake up in the morning, my heart is beating.

15X I expect things to turn out for the best.

16X If find it difficult to talk with a person I have just met.

$17 Y$ I could assist in a surgical operation without fainting if I had to.

18Y I would hate to make a loan to a poor family I didn't know very well.

19x You can get what is coming to you without having to be aggressive or competitive.

$20 Y$ Living according to schedule is something I like to avoid.

$21 Y$ The laws governing the people of this country are sound and need only minor changes, if any.

22X I seem to lack the drive necessary to get things done.

$23 y$ If the world were to be totally destroyed tomorrow, I could still go on the way I have been. 
24X I feel so down-in-the-dumps that nothing can cheer me up.

25X At a party I like to meet as many people as I can.

26x A sad movie makes me feel like crying.

$27 Y$ I enjoy helping people even if I don't know them very well.

$28 x$ Some people will deliberately say or do things to hurt you.

29X I will go to great lengths to correct mistakes in my work which other people wouldn't even notice.

30X I ignore what my neighbors might think of me.

31X I can work a long time without feeling tired.

$32 Y$ At one time or another in my life, I have been afraid.

33X My mood remains rather constant, neither going up nor down.

$34 \mathrm{Y}$ It would be hard for me to do anything in front of an audience.

35X I can tolerate vulgarity.

36X I take care of myself before I think about other people's needs.

$37 Y$ Most people are valuable human beings.

$38 \mathrm{X}$ My room is a mess.

39 Y Young people should be more willing than they are to do what their elders tell them to do.

$40 Y$ Being a big success in life requires more effort than I am willing to make.

41X My morals are above reproach.

$42 X$ My nerves seem on edge.

$43 x$ It is easy for me to talk with people.

44X I like movies which tell the story of two people in love.

$45 Y$ I would like to devote my life to the service of others.

$46 Y$ Most public officials would accept bribes if they were large enough. 
47X If I come into a house where everything is in disorder, I get a very negative reaction.

48X People who break the law while protesting bad social conditions should get off without punishment.

49X I enjoy doing things that involve quite a bit of physical exercise.

50X I have done things of a sexual nature that society does not approve of.

51X I am free of inferiority feelings.

$52 \mathrm{X}$ In a group of people I keep quiet.

$53 Y$ I could pick up a non-poisonous snake with my bare hands without being afraid.

54X I am inclined to be unsympathetic.

$55 Y$ Most people try hard to be unselfish.

56X I enjoy taking chances.

$57 X$ If a law is bad you should obey it and try to get it changed rather than disobey it.

$58 \times$ Hard work is an activity which I like to avoid, if possible.

59x My table manners at home are just as good as they are when I am invited out for dinner.

$60 Y$ I am inclined to be a pessimist.

61X I find it easy to start a conversation with a stranger.

$62 Y$ Seeing a lot of blood would make me feel faint.

63X I am generous with the poor.

64 Y You don't get far unless you are ready to fight off the competition.

65X I like to maintain a regular schedule of activities.

66X I am critical of the way our present society is organized.

$67 X$ I seem to have lots of vim and vigor.

$68 \times$ I eat too much. 
69X Things have worked out well for me.

70Y I try to avoid contacts with new people.

$71 x$ It would be hard to make me cry.

$72 x$ If someone is looking for help, I try to make myself scarce.

73X If somebody does something which hurts me, my tendency is to believe it was unintentional.

74X If I get the most important part of a job done right, I forget about the little details.

$75 \mathrm{Y}$ It is important for me to be accepted in my community.

76X I need to allow a lot of time to stop and rest.

77X I give every penny I can to charity.

78Y I shift a great deal between high spirits and low spirits.

79Y It would be easy for me to make a speech.

$80 \mathrm{Y}$ Some jokes are so crude and disgusting that they almost make me $i 11$.

$81 \mathrm{X}$ I think it is more important for those I love to be happy than it is for me to be happy.

82Y Most people aren't worth the room they take up.

83X I keep everything in its proper place so I know just where to find it.

$84 \mathrm{Y} \mathrm{High} \mathrm{school} \mathrm{boys} \mathrm{should} \mathrm{be} \mathrm{allowed} \mathrm{to} \mathrm{wear} \mathrm{their} \mathrm{hair} \mathrm{long} \mathrm{and}$ shaggy if they want to.

85X I am willing to work very hard to get ahead of the next fellow.

$86 \mathrm{Y}$ I have been guilty of stealing at one time or another during my life.

$87 x$ I relax without difficulty.

88x After being introduced to someone, I have difficulty thinking of something to say.

89X A book about love and romance would bore me. 
$90 y$ I would try to avoid a job in which I had to help people with their problems.

$91 Y$ Most public servants are trustworthy.

92X I feel more relaxed and comfortable around people who aren't always worried about things being clean and tidy.

93Y Law enforcement agencies should have greater powers than they do now to put law breakers behind bars and keep them there.

94X I hate vigorous physical activities that get me all sweaty and overheated.

95X If a pay telephone refunded too much money, I would put it back in the phone.

96X I have the feeling that the people I know are better than I am.

97X I love to talk.

98Y Having a slimy creature crawl over my legs would really bother me.

99X I am a very sympathetic person.

100Y Most people are out to get more than they give.

101X I like to play it safe.

102X If I can get away with it, I will break any law which I think is bad.

103X I like to work hard.

104X If it is convenient for me to do so, I will iie.

105X I am optimistic.

106X At a party, I find it hard to mix with people I don't know.

$107 Y$ I could and would drink blood if I was thirsty and had nothing else available.

108X My inclination is to give as little to charity as my conscience will allow.

109x 0ther people will give you what you are entitled to without your having to fight for it. 
110Y Living in an orderly way bores me.

111X I believe the society we live in is pretty good the way it is.

$112 y$ I seem to be less energetic than most other people.

113x In choosing my friends, I ignore things like race, religion, and political beliefs.

114X The future looks so gloomy that I wonder if I should go on.

115X I enjoy meeting new people.

116X I am easily moved to tears.

117X I like to help people even if they don't know who did it.

118X I seem to run into people who have a mean streak in them.

119X I am a perfectionist in my work.

120X I am inclined to disregard what the public may think about me.

121X I have a great deal of endurance.

$122 y$ In school, I cheated at one time or another.

123X I stay on an even keel emotionally.

124Y I get stage fright easily.

$125 Y$ I enjoy crude bathroom humor.

126X I am a rather selfish person.

$127 Y$ Most people have a lot more good than bad in them.

128X I am disorderly.

129X People should be careful to dress properly when they are away from home.

130X I lack ambition.

131X In anything I do, I really try to do the very best I can.

132X I have difficulty trying to calm down. 
133x When I am with someone else it is easy for me to find something to talk about.

134X I like to think about falling in love.

135X I have a strong desire to do something for the good of humanity.

136Y Most people would cheat if they could get away with it.

137X When people don't keep things spic and span, it bothers me.

$138 \times$ The police in this society abuse their powers.

139x I like to work up a good sweat.

140Y There have been times in my life when I acted like a coward.

141X I thing I am just as good as the people I know.

142X I do less than my share of the talking in a conversation.

143X I enjoy having spiders close by so I can watch them.

144X I am rather insensitive to the difficulties that other people are having.

145X The average person will put the welfare of those close to him ?: of his own personal needs.

146X I like to live dangerously.

147X I obey the law even when I am convinced it is in need of change.

148X I believe it is better not to work too hard.

149Y I believe that my body will live forever.

150X I expect the worst to happen.

151X I feel comfortable with people I have never even seen before.

152X The sight of blood tends to make me $i 11$.

153X I am willing to share what I can with others less fortunate.

154X If you aren't willing to fight, people will walk all over you.

155X I like my life to be orderly and well-planned in advance. 
156Y I would make a lot of changes in the laws of this country if I could.

157X Other people think I am an energetic person.

158Y There are some things that I do not understand.

159x When I look back, I think that life has been good to me.

160X I keep to the people I already know instead of seeking new friends.

161Y I am too well controlled to ever break down and cry.

$162 X$ I try to get out of helping other people if I can.

163X Most people would go out of their way to avoid hurting somebody else.

164X If the mistakes in my work are only minor ones, I forget about them.

165X I want the people in my neighborhood to have a good opinion of me.

166x I tire quickly.

$167 Y$ I believe that I am the one and only person of this earth to whom God has spoken personaliy.

$168 Y$ My moods change quick $7 y$ and easily.

169 It would be easy for me to act a part in a play.

$170 y$ There are certain words which are so vulgar that I would never use them.

171X I like to look after the welfare of the ones I love before I worry about myself.

$172 Y$ Most people make me sick.

173X I am very fussy about where I put my belongings.

$174 Y$ University students should be allowed to demonstrate publicly as a form of social protest.

$175 Y$ I have a very strong desire to get to the top.

176y There are certain people on this earth that I do not know personaliy. 
177X I am free of tension.

178x In a group of people, I find myself at a loss for words.

179x I have more important things to do than spending time thinking about love and romance.

180y It would be hard for me to spend my life serving other people. 


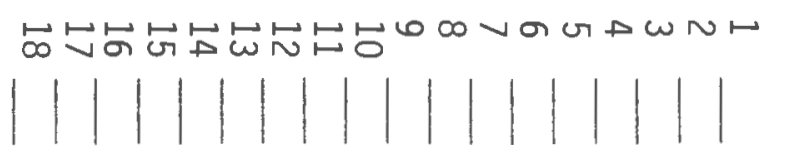

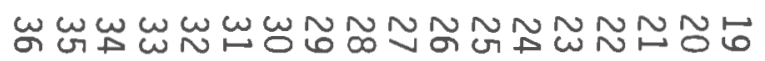

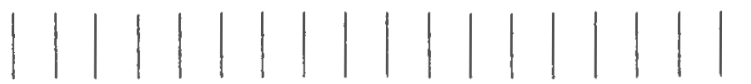

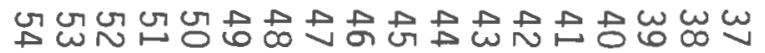

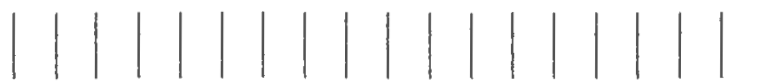

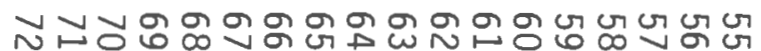

1111111111111111

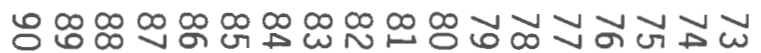

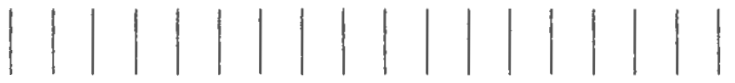

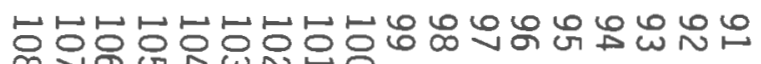
||$^{\infty}||^{n}||^{\infty}|1| 1 \mid 1$

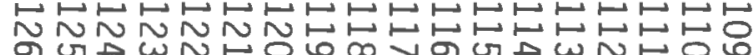

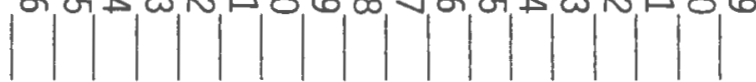

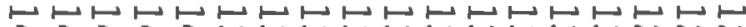

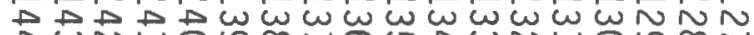
$\rightarrow \omega N \mapsto 0 \omega \infty V \sigma \in \omega N \mapsto 00 \infty \%$

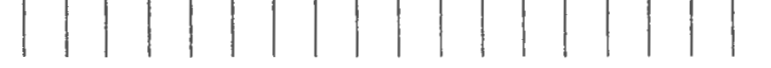

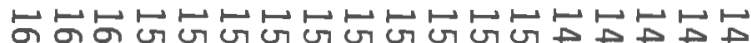

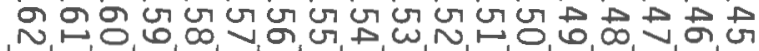

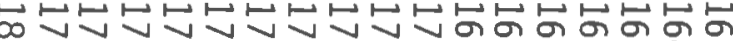
0,
คN

$z<\infty 0 \pi<D$

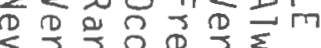

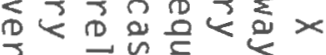

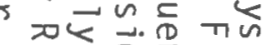

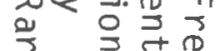

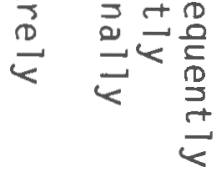

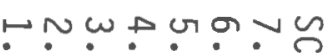

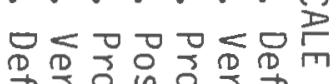

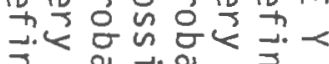

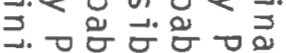

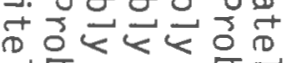

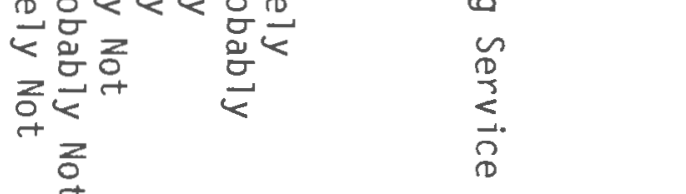

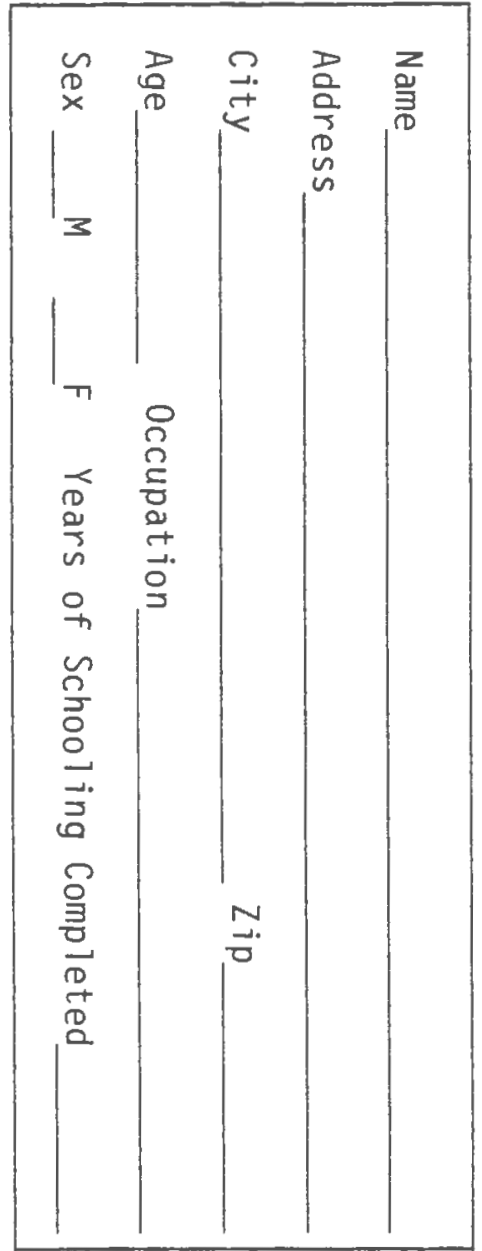


COMREY PERSONALITY SCALES

ITEMS LISTED BY SCALE

TRUST(T) VS. DEFENSIVENESS(D)

Range

a. Lack of Cynicism

1. The average person is honest.

46. Most public officials would accept bribes if they were $\quad 1=T \quad 7=0$ large enough.

91. Most public servants are trustworthy.

$7=T \quad 1=D$

136. Most people would cheat if they could get away with it. $\quad 1=T \quad 7=0$

b. Lack of Defensiveness

19. You can get what is coming to you without having to be $7=T \quad 1=0$ aggressive or competitive.

64. You don't get far unless you are ready to fight off the $1=T 7=0$ competition.

109.0ther people will give you what you are entitled to without $7=T \quad 1=0$ your having to fight for it.

154. If you aren't willing to fight, people will walk all over $1=T$ 7=D you.

c. Belief in Human Worth

37. Most people are valuable human beings.

82. Most people aren't worth the room they take up.

$7=T \quad 1=D$

127. Most people have a lot more good than bad in them $\quad 7=T \quad 1=0$

172. Most people make me sick.

d. Trust in Human Nature

10. Other people are selfishly concerned about themselves in $1=T \quad 7=0$ what they do.

55. Most people try hard to be unselfish.

100. Most people are out to get more than they give.

$7=T \quad 1=0$

$1=T \quad 7=0$

145. The average person will put the welfare of those close to $7=T \quad 1=0$ him ahead of his personal needs.

e. Lack of Paranoia

28. Some people will deliberately say or do things to hurt you. $1=T 7=0$

73. If somebody does something which hurts me, my tendency is $7=T 1=0$ to believe it was unintentional.

118. I seem to run into people who have a mean streak in them. $1=T 7=0$

163. Most people would go out of their way to avoid hurting $\quad 7=T \quad 1=0$ somebody else. 
ORDERLINESS(O) vS. LACK OF COMPULSION(L)

a. Neatness

Range

2. I could live in a pig pen without letting it bother me. $\quad 1=0 \quad 7=\mathrm{L}$

47. If I come into a house where everything is in disorder, $\quad 7=0 \quad 1=L$ I get very negative reaction.

92. I feel more relaxed and comfortable around people who $1=0 \quad 7=L$ aren't always worried about things being clean and tidy.

137. When people don't keep things spic and span, it bothers me. $7=0 \quad 1=\mathrm{L}$

b. Routine

20. Living according to a schedule is something I like to avoid. $1=0 \quad 7=L$ 65. I like to maintain a regular schedule of activities. $\quad 7=0 \quad 1=L$ 110.Living in an orderly way bores me. $\quad 1=0 \quad 7=L$ 155. I like my life to be orderly and well-planned in advance. $\quad 7=0 \quad 1=L$

c. Order

38. My room is a mess.

$1=0 \quad 7=\mathrm{L}$

83. I keep everything in its proper place so I know just where $7=0 \quad I=L$ to find it.

128. I am disorderly.

173. I am very fussy about where I put my belongings.

$1=0 \quad 7=$

$7=0 \quad i=L$

d. Cautiousness

11. I am a very cautious person.

56. I enjoy taking chances.

101. I like to play it safe.

146. I like to live dangerous ly.

$7=0 \quad 1=L$

$1=0 \quad 7=L$

$7=0 \quad 1=L$

$1=0 \quad 7=L$

\section{e. Meticulousness}

29. I will go to great lengths to correct mistakes in my work $7=0 \quad 1=\mathrm{L}$ which other people wouldn't even notice.

74. If I get the most important part of a job done right, I $1=0 \quad 7=L$ forget about the little details.

119. I am a perfectionist in my work.

$7=0 \quad 1=L$ 
SOCIAL CONFORMITY(C) vS. REBELLIOUSNESS(R)

a. Law Enforcement $\quad$ Range

3. This society provides too much protection for criminals. $\quad 7=C \quad I=R$

48. People who break the law while protesting bad social $\quad I=C \quad 7=R$ conditions should get off without punishment.

93. Law enforcement agencies should have greater powers than $7=C \quad 1=R$ they do now to put law breakers behind bars and keep them there.

138. The police in this society abuse their powers. $\quad I=C \quad 7=R$

b. Acceptance of the Social Order

21. The laws governing the people of this country are sound $7=C \quad 1=R$ and need only minor changes, if any.

66. I am critical of the way our present society is organized. $1=C \quad 7=R$

111. I believe the society we live in is pretty good the way it $7=C \quad 1=R$ is.

156. I would make a lot of changes in the laws of this country $1=C \quad 7=R$ if I could.

c. Intolerance of Non-Conformity

39. Young people should be more willing than they are to do $7=C \quad 1=R$ what their elders tell them to do.

84. High school boys should be allowed to wear their hair long $1=C \quad 7=R$ and shaggy if they want to.

129. People should be careful to dress properly when they are $7=C \quad 1=R$ away from home.

174. University students should be allowed to demonstrate

$1=C \quad 7=R$ publicly as a form of social protest.

d. Respect for Law

12. If the laws of society are unjust, they should be disobeyed. $1=C \quad 7=R$

57. If a law is bad you should obey it and try to get it $\quad 7=C \quad 1=R$ changed.

102. If I can get away with it, I will break any law which I $1=C \quad 7=R$ think is bad.

147. I obey the law even when I am convinced it is in need of $7=C \quad 1=R$ change.

e. Need for Approval

30. I ignore what my neighbors might think of me. $\quad 1=C \quad 7=R$

75. It is important for me to be accepted in my community. $\quad 7=C \quad 1=R$

120. I am inclined to disregard what the public may think $\quad I=C \quad 7=R$ about me.

165. I want the people in my neighborhood to have a good opinion $7=C \quad 1=R$ of me. 
ACTIVITY (A) VS. LACK OF ENERGY(L)

a. Exercise Range

4. If I think about exercising, I lie down until the idea goes $1=A \quad 7=L$ away.

49. I enjoy doing things that involve quite a bit of physical $7=A \quad I=L$ exercise.

94. I hate vigorous activities that get me all sweaty and over- $1=A \quad 7=L$ heated.

139. I like to work up a good sweat.

$7=\mathrm{A} \quad 1=\mathrm{L}$

b. Energy

22. I seem to lack the drive necessary to get things done. $\quad 1=A \quad 7=L$

67. I seem to have lots of vim and vigor.

112. I seem to be less energetic than most other people.

$7=A \quad 1=L$

157.0ther people think I am an energetic person.

$1=A \quad 7=\mathrm{L}$

$7=\mathrm{A} \quad 1=\mathrm{L}$

c. Need to Excel

40. Being a big success in life requires more effort than I am $1=A \quad 7=L$ willing to make.

85. I am willing to work very hard to get ahead of the next $7=A \quad I=L$ fellow.

130. I lack ambition.

175. I have a very strong desire to get to the top.

$1=A \quad 7=L$ $7=A \quad 1=L$

d. Liking for Work

13. I love to work long hours.

$7=A \quad 1=L$

58. Hard work is an activity which I like to avoid if possible. $1=A \quad 7=L$ 103. I like to work hard.

148. I believe it is better not to work too hard.

$7=A \quad 1=L$

$1=A \quad 7=L$

e. Stamina

31. I can work a long time without feeling tired.

76. I need to allow a lot of time to stop and rest.

121. I have a great deal of endurance.

166. I tire quickly.

$7=\mathrm{A} \quad 1=\mathrm{L}$

$1=A \quad 7=\mathrm{L}$

$7=A \quad 1=\mathrm{L}$

$I=A \quad 7=L$ 
EMOTIONAL STABILITY(S) vS. NEUROTICISM(N)

a. Lack of Inferiority Feelings

Range

6. I feel inferior to the people I know.

$1=\mathrm{S} \quad 7=\mathrm{N}$

51. I am free of inferiority feelings.

$7=\mathrm{S} \quad 1=\mathrm{N}$

96. I have the feeling that the people I know are better than $1=S \quad 7=N$ I am.

141. I think I am just as good as the people I know. $\quad 7=\mathrm{S} 1=\mathrm{N}$

b. Lack of Depression

24. I feel so down-in-the-dumps that nothing can cheer me up. $1=\mathrm{S} 7=\mathrm{N}$ 69. Things have worked out well for me. $\quad 7=S \quad 1=N$ 114. The future looks so gloomy that I wonder if I should go on. $1=\mathrm{S} 7=\mathrm{N}$ 159. When I look back, I think that life has been good to me. $7=51=\mathrm{N}$

c. Lack of Agitation

42. My nerves seem to be on edge.

87. I relax without difficulty.

132. I have difficulty trying to calm down.

177. I am free of tension.

$1=\mathrm{S} 7=\mathrm{N}$

$7=\mathrm{S} \quad 1=\mathrm{N}$

$1=S \quad 7=\mathrm{N}$

$7=\mathrm{S} \quad 1=\mathrm{N}$

d. Lack of Pessimism

15. I expect things to turn out for the best.

$7=\mathrm{S} \quad 1=\mathrm{N}$

60. I am inclined to be a pessimist.

105. I am optimistic.

150. I expect the worst to happen.

$1=\mathrm{S} \quad 7=\mathrm{N}$

$7=\mathrm{S} \quad 1=\mathrm{N}$

$1=\mathrm{S} \quad 7=\mathrm{N}$

e. Mood Stability

33. My mood remains rather constant, neither going up nor down. $7=\mathrm{S} 1=\mathrm{N}$ 78. I shift a great deal between high spirits and low spirits. $1=\mathrm{S} 7=\mathrm{N}$ 123. I stay on an even keel emotionally. 168. My moods change quickly and easily.

$7=\mathrm{S} \quad 1=\mathrm{N}$ $1=\mathrm{S} \quad 7=\mathrm{N}$

EXTRAVERSION(E) VS. INTROVERSION(I)

a. Lack of Reserve

7. I am a very talkative person.

52. In a group of people I keep quiet.

$7=\mathrm{E} \quad 1=\mathrm{I}$

97. I love to talk.

$1=E \quad 7=I$

142. I do less than my share of the talking in a conversation. 
b. Lack of Seclusiveness

Range

25. At a party I like to meet as many people as I can.

$7=E \quad 1=I$

70. I try to avoid contacts with new people.

$1=E \quad 7=I$

115. I enjoy meeting new people.

$7=\mathrm{E} \quad 1=\mathrm{I}$

160. I keep to the people I already know instead of making new $1=E \quad 7=I$ friends.

c. No Loss for Words

43. It is easy for me to talk with people.

88. After being introduced to someone, I have difficulty think- $1=E \quad 7=I$ ing of something to say.

133. When I am with someone else it is easy for me to find some- $7=E \quad 1=I$ thing to talk about.

178. In a group of people, I find myself at a loss for words. $\quad 1=E \quad 7=I$

d. Lack of Shyness

16. I find it difficult to talk with a person I have just met. $I=E \quad 7=I$ 61. I find it easy to start a conversation with a stranger $7=E \quad 1=I$ 106. At a party, I find it hard to mix with people I don't know. $I=E \quad 7=I$ 151. I feel comfortable with people I have never even seen $\quad 7=E \quad I=I$ before.

e. No Stage Fright

34. It would be hard for me to do anything in front of an $1=E \quad 7=I$ audience

79. It would be easy for me to make a speech.

124. I get stage fright easily.

169. It would be easy for me to act a part in a play.

$7=\mathrm{E} \quad 1=\mathrm{I}$

$1=E \quad 7=I$

$7=E \quad I=I$

MASCULINITY(M) VS. FEMININITY(F)

a. No Fear of Bugs

8. Big bugs and other crawling creatures upset me. $\quad 1=M \quad 7=F$

53. I could pick up a non-poisonous snake with my bare hands $7=M \quad I=F$ without being afraid.

98. Having a slimy creature crawl over my leg would really $1=M \quad 7=F$ bother me.

143. I enjoy having spiders close by so I can watch them. $\quad 7=M \quad 1=F$

b. No Crying

20́. A sad movie makes me feel like crying. $\quad 1=M \quad 7=F$

71. It would be hard to make me cry. $\quad 7=M \quad I=F$

116. I am easily moved to tears.

$161 . I$ am too well controlled to ever break down and cry. $\quad 7=M \quad 1=F$ 
c. No Romantic Love

Range

44. I like movies which tell the story of two people in love.

$1=M \quad 7=F$

89. A book about love and romance would bore me.

$7=M \quad 1=F$

134. I like to think about falling in love.

179. I have more important things to do than spending time

$1=M \quad 7=F$ thinking about love and romance.

$7=M \quad 1=F$

d. Tolerance of Blood

17. I could assist in a surgical operation without fainting $7=M \quad 1=F$ if I had to.

62. Seeing a lot of blood would make me feel faint.

107. I could and would drink blood if I were thirsty and had nothing else available.

152. The sight of blood tends to make me $i 11$.

$1=M \quad 7=F$

$7=M \quad 1=F$

$1=M \quad 7=F$

e. Tolerance of Vulgarity

35. I can tolerate vulgarity. $\quad 7=M \quad 1=F$

80. Some jokes are so crude and disgusting that they almost $\quad 1=M \quad 7=F$ make me ill.

125. I enjoy crude bathroom humor. $\quad 7=M \quad 1=F$

170. There are certain words which are so vulgar that I would $1=M \quad 7=F$ never dare use them.

$\operatorname{EMPATHY}(P)$ VS. EGOCENTRISM(E)

a. Sympathy

9. I am very kindhearted.

54. I am inclined to be unsympathetic.

99. I am a very sympathetic person.

144. I am rather insensitive to the difficulties that other people are having.

b. Helpfulness

27. I enjoy helping people even if I don't know them very well. $7=\mathrm{P} \quad 1=\mathrm{E}$ 72. If someone is looking for help, I try to make myself scarce.1 $=P \quad 7=E$ 117. I like to help people even if they don't know who did it. $\quad 7=P \quad 1=E$ 162. I try to get out of helping other people if I can. $\quad 1=P \quad 7=E$ 
45. I would like to devote my life to the service of others. $\quad 7=P \quad 1=E$ 90. I would try to avoid a job in which I had to help other $1=P \quad 7=E$ people with their problems.

135. I have a strong desire to do something for the good of $\quad 7=P \quad 1=E$ humanity.

180. It would be hard for me to spend my life serving other $\quad 1=P \quad 7=E$ people.

\section{d. Generosity}

18. I would hate to make a loan to a poor family I didn't know $1=P \quad 7=E$ very well.

63. I am generous with the poor.

108. My inclination is to give as little to charity as my $7=P \quad 1=E$ conscience will allow.

153. I am willing to share what I can with others less fortunate. $7=P \quad 1-E$

e. Unselfishness

36. I take care of myself before I think about other people's $1=P \quad 7=E$ needs.

81. I think it is more important for those I love to be happy $7=P \quad 1=E$ than it is for me to be happy.

126. I am a rather selfish person.

171. I like to look after the welfare of the ones I love before $7=P \quad 1=E$ I worry about myself.

VALIDITY (V) VS. NON-VALIDITY(N)

5. If I were asked to lift a ten-ton weight, I could do it. $\quad 1=V \quad 7=\mathrm{N}$

14. When I wake up in the morning, my heart is beating. $\quad 7=V \quad 1=N$

23. If the world were to be totaliy destroyed tomorrow, I $\quad 1=V \quad 7=\mathrm{N}$ could still go on the way I have been.

32. At one time or another in my life, I have been afraid. $\quad 7=\mathrm{V} \quad 1=\mathrm{N}$

149. I believe that my body will live forever. $\quad 1=V \quad 7=\mathrm{N}$

158. There are some things that I do not understand. $\quad 7=\mathrm{V} \quad 1=\mathrm{N}$

167. I believe that I am the one and only person of this earth $1=V \quad 7=\mathrm{N}$ to whom God has spoken personaliy.

176. There are certain people on this earth that I do not know $7=\mathrm{V} 1=\mathrm{N}$ personally. 
41. My morals are above reproach.

50. I have done things of a sexual nature that society does $I=R \quad 7=N$ not approve of.

59. My table manners at home are just as good as they are when $7=R \quad I=N$ I am invited out for dinner.

68. I eat too much.

$1=\mathrm{R} \quad 7=\mathrm{N}$

77. I give every penny I can to charity.

$7=R \quad I=N$

86. I have been guilty of stealing at one time or another in $1=\mathrm{R} \quad 7=\mathrm{N}$ my life.

95. If a pay telephone refunded too much money, I would put it $7=\mathrm{R} \quad 1=\mathrm{N}$ back in the phone.

104. If it is convenient for me to do so, I will lie.

$1=\mathrm{R} \quad 7=\mathrm{N}$

113. In choosing my friends, I ignore things like race, $7=\mathrm{R} \quad 1=\mathrm{N}$ religion, and political beliefs.

122. In school, I cheated at one time or another. $\quad 1=R \quad 7=\mathrm{N}$ 131. In anything I do, I really try to do the very best I can. $7=R \quad 1=\mathrm{N}$ 140. There have been times in my life when I acted like a coward.1=R $7=\mathrm{N}$ 


\section{BIBLIOGRAPHY}

Aberle, D.F., \& Naegele, F.D. (1952). Middle-class fathers' occupational role and attitude toward children. American Journal of orthopsychiatry, 22, 366-378.

Baumrind, D., \& Black. A.E. (1967). Socialization practices associated with dimensions of competence in preschool boys and girls. Child Development, 38, 291-327.

Bergenstal, Karl W. (1981). The relationship of father support and father availability to adolescent sons' experience of loneliness and separation anxiety. Dissertation Abstracts International, 42, 2024-B.

Bieri, J. (1960). Parental identification, acceptability, and authority, and within-sex differences in cognitive behavior. Journal of Abnormal and Social Psychology, 60, 76-79.

Biller, H.B. (1969). Father dominance and sex-role development in kindergarten age boys. Developmental Psychology, 1, 87-94.

Biller, H.B. Father, child, and sex-role. Lexington, Mass: Heath.

Biller, H.B., (1974). Paternal deprivation: Family, school, sexuality, and society. Lexington, Mass: Lexington Books, D.C. Heath and Company.

Biller, H.B. \& Meredith, D.L. (1974). Father power. New York: David McKay, 1974; Reprinted, New York: Doub leday Anchor Books, 1975.

Biller, H.B. \& Weiss, S. (1970). The father-daughter relationship and the personality development of the female. Journal of Genetic Psychology, 114, 79-93.

Biller, H.B., \& Solomon, R.S. (1986). Child maltreatment and paternal deprivation: A minifesto for research, prevention, and treatment. Lexington, Mass: D.C. Heath and Company. 
Blanchard, R.W., \& Biller, H.B. (1971). Father availability and academic performance among third grade boys. Developmental Psychology, 4 , 301-305.

Block J. (1971). Lives through-time. Berkeley, Ca.: Bancroft Books.

Block, J.; von der Lipp, A.; \& Block, J.H. (1973). Sex role and socialization: Some personality concomitants and environmental antecedents. Journal of Consulting and Clinical Psychology, 41, 321-341.

Brofenbrenner, U. (1961). Some familial antecedents of responsibility and leadership in adolescents. In L. Petrullo \& B.M. Bass (Eds.), Leadership and interpersonal behavior. New York: Holt, Rinehart, and Winston, pp. 239-272.

Brunkan, R.J., \& Crites, J.0. (1964). An inventory to measure the parental attitude variables in Roe's theory of vocational choice. Journal of Counseling Psychology, 11, 3-12.

Cattell, R.B. (1965). The scientific analysis of personality. Baltimore: Penguin.

Comrey, R.B., (1970). Comrey Personality Scales. San Diego, Ca.: Educational and Industrial Testing Service.

Comrey, R.B., \& Backer, T.E. (1970). Construct validation of the Comrey Personality Scales. Multivariate Behavioral Research, 5, 469-477.

Coopersmith, S. (1967). The antecedents of self-esteem. San Francisco: W.H. Freeman.

Crandall, et al. (1964). Parents' attitudes and behaviors and gradeschool children's academic achievements. Journal of Genetic Psychology, 104, 53-66.

Distler, L.S. (1964). Patterns of parental ident ification: An examination of three theories. Ph.D. dissertation, University of California, BerkeTey. 
Epstein, A. \& Radin, N. (1976). Motivational components related to father behavior and cognitive functioning in preschoolers, Child Development, 46, 831-389.

Eysenck, H.J. \& Eysenck, S.B.G. (1969). Personality structure and measurement. San Diego: Knapp.

Fish, K.D. \& Biller, H.B. (1973). Perceived childhood paternal relationships and college females' personal adjustment, Adolescence, $\underline{8}$, 415-420.

Goodenough, E.W. (1957). Interest in persons as an aspect of sex differences in the early years. Genetic Psychology Monographs, 55, 287-323.

Guilford, J.P. (1959), Personality. New York: McGraw-Hill.

Hansen, M.D. (1988). Paternal acceptance and nurturance received and fathers' acceptance and nurturance of their sons, Unpublished Master's Thesis, University of Rhode Island, Kingston, Rhode Island.

Heilbrun, A.B., Jr. (1965). An empirical test of the modeling theory of sex-role learning. Child Development, 36, 789-799.

Heilbrun, A.B., Jr. (1974). Parent identification and filial sex-role behavior: The importance of biological context. In J.C. Cole \& R. Dienstbier (Eds.), Nebraska Symposium on Motivation, 1973. Lincoln: University of Nebraska Press, pp. 125-194.

Hetherington, E.M.; Cox, M.; \& Cox, R. (1978). The aftermath of divorce. In J.H. Stevens \& M. Mathews (Eds.), Motherchild fatherchild relationships. Washington, D.C.; National Association for the Education of Young Children.

Hetherington, E.M.; Cox, M.; \& Cox, R. (1982). Effects of divorce on parents and children. In M.E. Lamb (Ed.) Nontraditional families, Hillsdale, New Jersey: Lawrence Erlbaum Associates.

Honzik, M.P. (1967). Environmental correlates of mental growth: Prediction from the family setting at 21 months. Child Development, 38, 388-364. 
Huck le, L.H. (1984). Personality correlates of parental maltreatment. Dissertation Abstracts Internationa $, 44,3592-B$.

Johnson, M.M. (1963). Sex-role learning in the nuclear family. Child Development, 34, 319-333.

Joreskog, K.G., \& Sorbom, D. (1984). LISREL VI. Mooresville, IN.: Scientific Software.

Lamb, M.E. (Ed.). (1976). The role of the father in child development. New York: Wiley.

Lamb, M.E. (1977). The development of parental preferences in the first two years of life. Sex Roles, 3, 495-497.

Lamb, M.E. (1978). Qualitative aspects of mother-infant and fatherinfant attachments. Infant Behavior and Development, $\underline{1}$, 265-275.

Lamb, M.E. (1979). Paternal influence and the father's role: A personal perspective. American Psychologist, 34, 938-943.

Lynn, D.B. (1974). The father: His role in child development. Belmont, Cal if.: Brooks/Cole.

Lynn, D.B. (1979). Daughters and parents: Past, present, and future. Belmont, calif.: Brooks/Cole.

Medinnus, G.N. (1965). Adolescents' self acceptance and perceptions of their parents. Journal of Consulting Psychology, 29, 150-154.

Mussen, P.H. (1961). Some antecedents and consequences of masculine sex-typing in adolescent boys. Psychological Monographs, 75, No. 2 (Whole No. 506).

Mussen, P.H. \& Distler, L. (1959). Masculinity, identification, and father-son relationships. Journal of Abnormal and Social Psychology, 59, 350-356. 
Mussen, P.H. \& Rutherford, E.E. (1963). Parent-child relationships and parental personality in relation to young children's sex role preferences. Child Development, 34, 589-607.

Nakamura, C.V., \& Rogers, M.M. (1969). Prents' expectations of autonomous behavior and children's autonomy. Developmental Psychology, $\underline{1}$, 613-617.

Parke, R.D. (1979). Perspectives on father-infant interaction. In J.D. Osofsky (Ed.), The handbook of infant development. New York: Wiley, pp. 549-590.

Parsons, T. (1955). Family Structure and the Socialization of the child. In T. Parsons \& R.F. Bales (Eds.), Family, socialization and interaction process. Glencoe, I11.: Free Press, pp. 25-131.

Payne, D.E. \& Mussen, P.H. (1956). Parent-child relations and father identification among adolescent boys. Journal of Abnormal and Social Psychology, 52, 358-362.

Plank, E.H. \& Plank, R. (1954). Emotional components in arithmetic learning as seen through autobiographies. Psychoanalytic Study of the Child, 9, 274-293.

Radin, N. (1972). Father-child interaction and the intellectual functioning of four-year-old boys. Developmental Psychology, $\underline{6}, 353-361$.

Radin N. (1974). Observed maternal behavior with four-year-old boys and girls in lower class families. Child Development, 45, 1126-1131.

Radin, N. (1976). The role of the father in cognitive, academic, and intel lectual development. In M.E. Lamb (Ed.), The role of the father in child development. New York: Wiley, pp. 237-267.

Radin, N. (1981). The role of the father in cognitive, academic, and intellectual development. In M.E. Lamb (Ed.), The role of the father in child development. (2nd Ed.). New York: Wiley, pp. $379-\overline{42} 7$. 
Reuter, M.W., \& Biller, H.B. (1973). Perceived paternal nurturanceavailability and personality adjustment among college males. Journal of Consulting and Clinical Psychology, 40, 339-342.

Rosenberg, M. (1965). Society and the adolescent self-image. Princeton, New Jersey: Princeton University Press.

Rothbart, M.K., \& Maccoby, E.E. (1966). Parents' differential reactions to sons and daughters. Journal of Personality and Social Psychology, $\underline{4}$, 237-243.

Sears, P.S. (1953). Child-rearing factors related to playing of sextyped roles. American Psychologist, $8,431$.

Sears, R.R. (1970). Relations of early socialization experiences to self-concepts and gender role in middle childhood. Child Development, 41, 267-289.

Sears, R.R.; Rau, L.; \& Alpert, R. (1965). Identification and child rearing. Stanford, Calif.: Stanford University Press.

Shaw, M.C. \& White, D.L. (1965). The relationship between child-parent identification and academic underachievement. Journal of Clinical Psychology, 21, 10-13.

Shinn, M. (1978). Father absence and children's cognitive development. Psychological Bulletin, 85, 295-324.

Torgoff, I. \& Dreyer, A.S. (1961). Achievement inducing and independence granting synergistic parental role components: Relation to daughter's parental role orientation and level of aspiration. American Psychologist, 16, 345 (Abstract).

Velicer, W.F. (1976). Determining the number of components from the matrix of partial correlations. Psychometrika, 41, 321-327.

Willemsen, E.; Flaherty, D.; Heaton, C.; \& Ritchey, G. (1974). Attachment behavior of one-year-olds as a function of mother vs. father, sex of child, session, and toys. Genetic Psychology Monographs, 90, 305-324. 
Zwick, W.R. \& Velicer, W.F. (1982). Factors influencing four rules for determining the number of components to retain. Multivariate Behavioral
Research, 17, 253-269. 